\title{
Article \\ Characterization of Human Medullary Thyroid Carcinoma Glycosphingolipids Identifies Potential Cancer Markers
}

\author{
Karin Säljö ${ }^{1,2}\left(\mathbb{D}\right.$, Anders Thornell ${ }^{2,3} \mathbb{\infty}$, Chunsheng Jin ${ }^{4}$, Olov Norlén ${ }^{5, *, \dagger}$ and Susann Teneberg ${ }^{4, *}+$ \\ 1 Department of Plastic Surgery, Institute of Clinical Sciences, Sahlgrenska Academy, University of Gothenburg, \\ S-41345 Gothenburg, Sweden; karin.saljo@vgregion.se \\ 2 Region Västra Götaland, Sahlgrenska University Hospital, S-41345 Gothenburg, Sweden; \\ anders.thornell@vgregion.se \\ 3 Department of Surgery, Institute of Clinical Sciences, Sahlgrenska University Hospital, \\ University of Gothenburg, S-41345 Gothenburg, Sweden \\ 4 Department of Medical Biochemistry and Cell Biology, Institute of Biomedicine, Sahlgrenska Academy, \\ University of Gothenburg, S-40530 Gothenburg, Sweden; chunsheng.jin@medkem.gu.se \\ 5 Department of Surgical Sciences, Uppsala University, S-75185 Uppsala, Sweden \\ * Correspondence: olov.norlen@surgsci.uu.se (O.N.); Susann.Teneberg@medkem.gu.se (S.T.) \\ + These authors contributed equally to this work.
}

check for updates

Citation: Säljö, K.; Thornell, A.; Jin, C.; Norlén, O.; Teneberg, S. Characterization of Human Medullary Thyroid Carcinoma Glycosphingolipids Identifies Potential Cancer Markers. Int. J. Mol. Sci. 2021, 22, 10463. https:// doi.org/10.3390/ijms221910463

Academic Editor: Alexander O Chizhov

Received: 7 September 2021

Accepted: 23 September 2021

Published: 28 September 2021

Publisher's Note: MDPI stays neutral with regard to jurisdictional claims in published maps and institutional affiliations.

Copyright: (c) 2021 by the authors. Licensee MDPI, Basel, Switzerland. This article is an open access article distributed under the terms and conditions of the Creative Commons Attribution (CC BY) license (https:/ / creativecommons.org/licenses/by/ $4.0 /)$.

\begin{abstract}
Medullary thyroid carcinoma (MTC) accounts for only 1-2\% of thyroid cancers; however, metastatic MTC is a mortal disease with no cure. In this study, glycosphingolipids were isolated from human MTCs and characterized by mass spectrometry and binding of carbohydrate recognizing ligands. The tissue distribution of selected compounds was investigated by immunohistochemistry. The amount of acid glycosphingolipids in the MTCs was higher than in the normal thyroid glands. The major acid glycosphingolipid was the GD3 ganglioside. Sulfatide and the gangliosides GM3 and GD1a were also present. The majority of the complex non-acid glycosphingolipids had type 2 (Galß4GlcNAc) core chains, i.e., the neolactotetraosylceramide, the Le ${ }^{\mathrm{x}}, \mathrm{H}$ type 2 and $\mathrm{x}_{2}$ pentaosylceramides, the $\mathrm{Le}^{\mathrm{y}}$ and $\mathrm{A}$ type 2 hexaosylceramides, and the A type 2 heptaosylceramide. There were also compounds with globo $(\mathrm{Gal} \alpha \mathrm{Gal} \beta 4 \mathrm{Glc})$ core, i.e., globotriaosylceramide, globotetraosylceramide, the Forssman pentaosylceramide, and the Globo $\mathrm{H}$ hexaosylceramide. Immunohistochemistry demonstrated an extensive expression av $\mathrm{Le}^{\mathrm{y}}$ in the MTC cells and also a variable intensity and prevalence of Globo $\mathrm{H}$ and $\mathrm{Le}^{\mathrm{x}}$. One individual with multiple endocrine neoplasia type $2 \mathrm{~B}$ expressed the Forssman determinant, which is rarely found in humans. This study of human MTC glycosphingolipids identifies glycans that could serve as potential tumor-specific markers.
\end{abstract}

Keywords: human medullary thyroid cancer marker; glycosphingolipid characterization; mass spectrometry; Lewis y antigen; Forssman antigen

\section{Introduction}

Medullary thyroid carcinoma (MTC) accounts for only 1-2\% of thyroid cancers [1]. Unlike the rather common follicular cell-derived thyroid cancers, papillary thyroid cancer and follicular thyroid cancer, MTC originates from parafollicular C-cells [2]. Thus, radioiodine imaging and treatment, successfully used for iodine-avid follicular cell-derived cancers, is not applicable to MTC. MTC also has a high propensity to metastasize both to lymph nodes and parenchymal organs rendering the disease difficult to cure with surgery, especially since MTC metastases can be difficult to image with currently available radiological methods. Chemotherapy has little effect in MTC, and available oncological treatments such as tyrosine kinase inhibitors offers partial response in less than $50 \%$ of all patients [3,4]. Therefore, a search for novel druggable targets for MTC is warranted.

One hallmark of cancer is aberrant glycosylation that is due to abnormally expressed glycosyltransferases and glycosidases in tumor cells and leads to the generation of tumorassociated carbohydrate antigens (TACAs) [5-8]. There are several different forms of 
cancer-associated alterations of cell surface glycoconjugates. TACAs may be due to an enhanced expression of certain carbohydrate structures, or an accumulation of precursor carbohydrate chains as well as appearance of novel carbohydrate structures. TACAs are of interest in the search for anti-cancer immunotherapeutics since they may allow the differentiation between tumor and normal cells.

The changes in protein glycosylation in thyroid cancers has been the subject of many studies (reviewed in $[9,10])$. However, there are only a few studies about thyroid cancer gangliosides [11,12]. Thus, a thorough characterization of thyroid cancer glycosphingolipids with the methods of today has not been conducted, and the non-acid glycosphingolipids have not been characterized. In this study we have isolated acid and non-acid glycosphingolipids of human MTCs. The glycosphingolipids were characterized by mass spectrometry, enzymatic digestion, and by binding of a battery of carbohydrate recognizing ligands, the tissue distribution of selected compounds was then investigated by immunohistochemistry.

\section{Results}

\subsection{Isolation of Human Medullary Thyroid Cancer Glycosphingolipids}

Total acid and non-acid glycosphingolipid fractions were isolated from pooled human medullary carcinomas of the thyroid by standard procedures [13]. This gave $15.6 \mathrm{mg}$ acid and $4.5 \mathrm{mg}$ non-acid glycosphingolipids/g dry weight tissue (Supplementary Table S1). In our recent study of glycosphingolipids of normal human thyroid gland, $2.0 \mathrm{mg}$ acid and $2.5 \mathrm{mg}$ non-acid glycosphingolipids/g dry weight tissue were obtained [14]. Thus, the amount of acid glycosphingolipids was substantially increased in the medullary thyroid cancers.

The total acid fraction is shown in Figure 1, lane 4. The major bands co-migrated with reference GD3 and GM3 gangliosides (Figure 1, lanes 5 and 6), and there was also a fast-migrating band in the sulfatide region. The total non-acid glycosphingolipid fraction (Figure 1, lane 3) had a number of compounds migrating as mono-, di-, tri- tetra- and pentaosylceramides, and also some minor slow-migrating compounds.

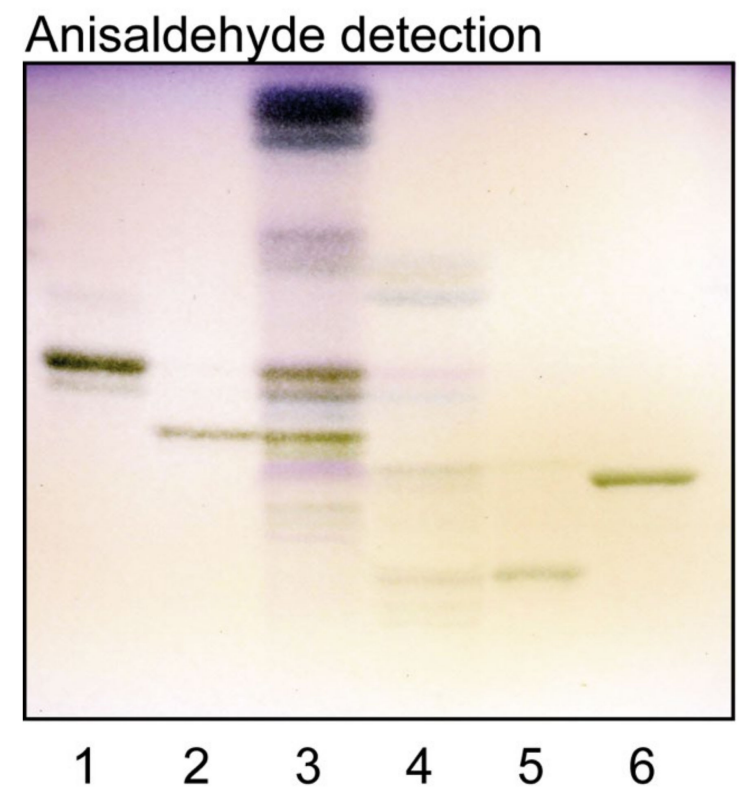

Figure 1. Thin-layer chromatography of the glycosphingolipids isolated from human medullary thyroid cancer. Thin-layer chromatogram after detection with anisaldehyde. Lane 1, reference globotriaosylceramide (Gal $\alpha 4 \mathrm{Gal} \beta 4 \mathrm{Glc} \beta 1 \mathrm{Cer}), 4 \mu \mathrm{g}$; lane 2, reference globotetraosylceramide (GalNAc $\beta 3$ Gal $\alpha 4$ Gal $\beta 4$ Glc $\beta 1$ Cer), $4 \mu \mathrm{g}$; lane 3, total non-acid glycosphingolipids isolated from human medullary thyroid cancer. $40 \mu \mathrm{g}$; lane 4 , total acid glycosphingolipids isolated from human medullary thyroid cancer. $40 \mu \mathrm{g}$; lane 5, reference GD3 ganglioside (Neu5Ac $\alpha 8 \mathrm{Neu} 5 \mathrm{Ac} \alpha 3 \mathrm{Gal} \beta 4 \mathrm{Glc} \beta 1 \mathrm{Cer}$ ), $4 \mu \mathrm{g}$; lane 6, reference GM3 ganglioside (Neu5Ac $\alpha 3$ Gal $\beta 4$ Glc $\beta 1$ Cer), $4 \mu \mathrm{g}$. 


\subsection{Characterization of the Acid Glycosphingolipids from Human Medullary Thyroid Cancer}

The native total acid glycosphingolipid fraction from human medullary thyroid cancer was analyzed by liquid chromatography-electrospray ionization mass spectrometry (LC-ESI/MS). The base peak chromatogram thereby obtained was dominated by doubly charged molecular ions at $m / z 721, m / z 763$ and $m / z 777$ (Figure 2A). MS ${ }^{2}$ of these ions (exemplified in Figure 2D) identified the GD3 ganglioside (see Table 1 for acid glycosphingolipid structures), with sphingosine and 16:0, 22:0 and 24:0 fatty acids, respectively.

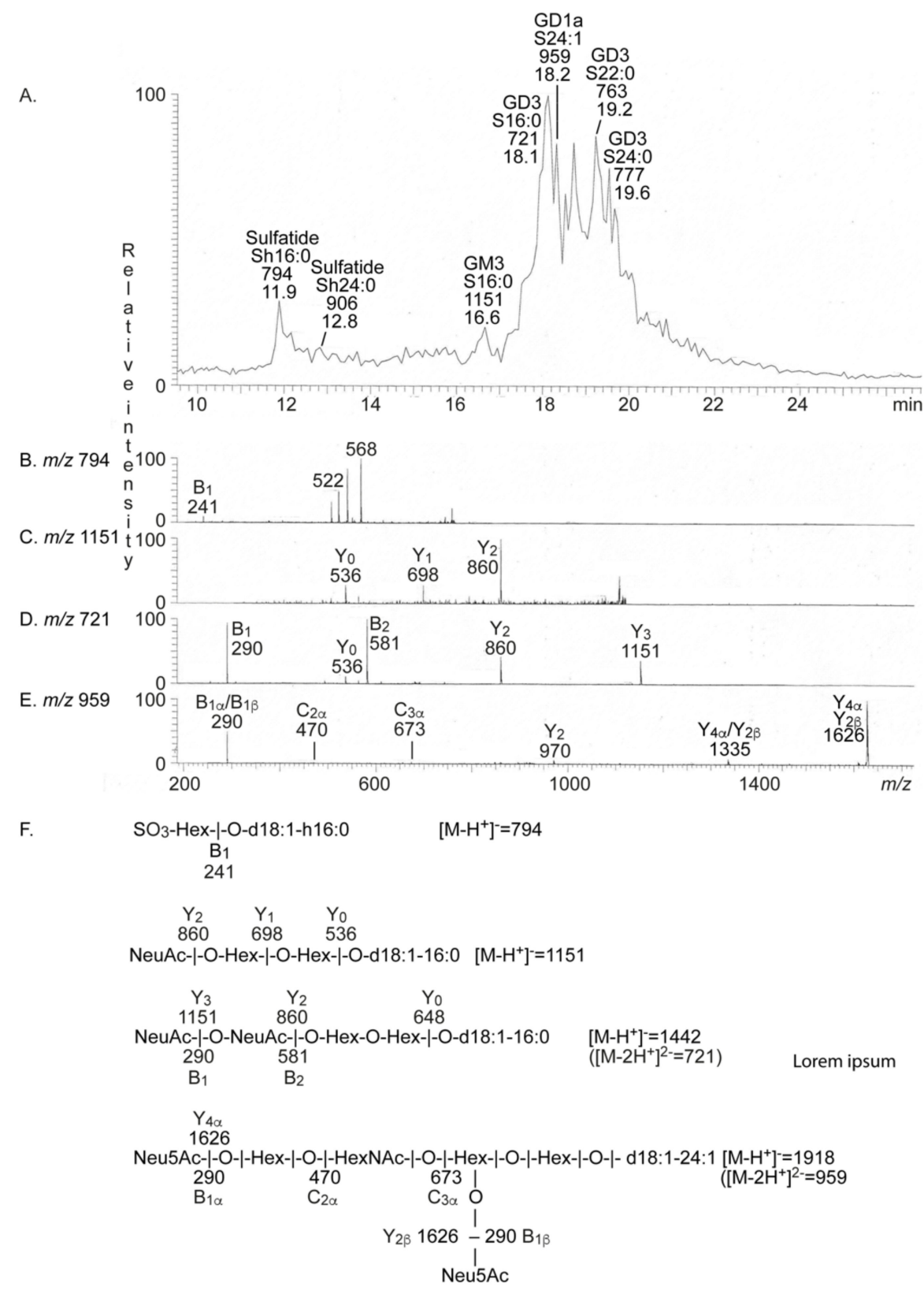

Figure 2. LC-ESI/MS of the total acid glycosphingolipid fraction from human medullary thyroid cancer. The identification of the glycosphingolipids was based on their retention times, determined molecular masses, and subsequent $\mathrm{MS}^{2}$ sequencing. (A) Base peak chromatogram from LC-ESI/MS of the total acid glycosphingolipid fraction from human medullary thyroid cancer. (B) $\mathrm{MS}^{2}$ of the ion at $m / z 794$ at retention time $11.9 \mathrm{~min}$. (C) $\mathrm{MS}^{2}$ of the ion at $\mathrm{m} / \mathrm{z} 1151$ at retention time $16.5 \mathrm{~min}$. (D) $\mathrm{MS}^{2}$ of the ion at $m / z 721$ at retention time $18.0 \mathrm{~min}$. (E) $\mathrm{MS}^{2}$ of the ion at $m / z 759$ at retention time $18.2 \mathrm{~min}$. 
(F) Interpretation formulas. The glycosphingolipids identified in the chromatogram were: Sulfatide, $\mathrm{SO}_{3}$-3Gal $\beta 1$ Cer; Neu5Ac-GM3, Neu5Ac $\alpha 3$ Gal $\beta 4$ Glc $\beta 1$ Cer; Neu5Ac-GD3, Neu5Ac $\alpha 8$ Neu5Ac $\alpha-$ 3Gal $\beta 4$ Glc $\beta 1$ Cer; Neu5Ac-GD1a, Neu5Ac $\alpha 3$ Gal $\beta 3$ GalNAc $\beta 4(N e u 5 A c \alpha 3) G a l \beta 4 G l c \beta 1 C e r$. In the shorthand nomenclature for fatty acids and bases, the number before the colon refers to the carbon chain length and the number after the colon gives the total number of double bonds in the molecule. Fatty acids with a 2-hydroxy group are denoted by the prefix $h$ before the abbreviation, as e.g., h16:0. $\mathrm{S}$ designates sphingosine (d18:1) long chain base.

Table 1. Glycosphingolipids identified by LC-ESI/MS in the total acid fraction from human medullary thyroid cancer.

\begin{tabular}{|c|c|c|}
\hline$m / z$ & Trivial Name & Structure \\
\hline 794 & Sulfatide & $\mathrm{SO}_{3}-3 \mathrm{Gal} \beta 1 \mathrm{Cer}$ \\
\hline 1151 & Neu5Ac-GM3 & Neu5Ac $\alpha 3$ Gal $\beta 4$ Glc $\beta 1$ Cer \\
\hline 721 & Neu5Ac-GD3 & Neu5Ac $\alpha 8$ Neu5Ac $\alpha 3$ Gal $\beta 4$ Glc $\beta 1$ Cer \\
\hline 959 & Neu5Ac-GD1a & Neu5Ac $\alpha 3$ Gal $\beta 3$ GalNAc $\beta 4($ Neu5Ac $\alpha 3)$ Gal $\beta 4$ Glc $\beta 1$ Cer \\
\hline
\end{tabular}

There were also two singly charged molecular ions at $m / z 794$ and $m / z 906$, and here sulfatide with sphingosine and hydroxy 16:0 and 24:0 fatty acids were characterized by $\mathrm{MS}^{2}$ (exemplified in Figure 2B). The GM3 ganglioside with sphingosine and 16:0 fatty acid was characterized by $\mathrm{MS}^{2}$ of the singly charged molecular ion at $m / z 1151$ (Figure 2C), and the GD1a ganglioside with sphingosine and 24:1 fatty acid was identified by $\mathrm{MS}^{2}$ of the doubly charged molecular ion at $\mathrm{m} / \mathrm{z} 959$ (Figure 2E). The presence of the GD1a ganglioside was confirmed by the binding of monoclonal anti-GD1a antibodies to the acid glycosphingolipid fraction from human medullary thyroid cancer (Supplementary Figure S1). Binding of monoclonal antibodies directed against sialyl-Le ${ }^{\mathrm{a}}$ was also tested but no binding was obtained (data not shown).

The glycosphingolipids characterized in the acid glycosphingolipid fraction are summarized in Table 1.

\subsection{Characterization of the Non-Acid Glycosphingolipids from Human Medullary Thyroid Cancer \\ 2.3.1. LC-ESI/MS of Glycosphingolipid-Derived Oligosaccharides}

The total non-acid glycosphingolipid fraction was hydrolyzed with endoglycoceramidase II from Rhodococcus sp., and the oligosaccharides thereby obtained were characterized by LC-ESI/MS using a graphitized carbon column. This method gives a resolution of isomeric oligosaccharides, and by $\mathrm{MS}^{2}$ a series of C-type ions is obtained, which gives the carbohydrate sequence [15]. Furthermore, the $\mathrm{MS}^{2}$ spectra of oligosaccharides with a Hex or HexNAc substituted at C-4 have diagnostic cross-ring ${ }^{0,2} \mathrm{~A}$-type and ${ }^{2,4} \mathrm{~A}$-type fragment ions, which allow identification of linkage positions $[15,16]$. Thus, such fragment ions are present in the $\mathrm{MS}^{2}$ spectra of oligosaccharides with globo (Gal $\alpha 4 \mathrm{Gal}$ ) or type 2 (Gal $\beta 4$ GlcNAc) core structures, but not in the $\mathrm{MS}^{2}$ spectra obtained from oligosaccharides with isoglobo (Gal $\alpha 3 \mathrm{Gal})$ or type 1 (Gal $\beta 3 \mathrm{GlcNAc}$ ) core chains. Comparison of retention times and $\mathrm{MS}^{2}$ spectra of oligosaccharides from reference glycosphingolipids is also used for identification of oligosaccharides.

The base peak chromatogram from LC-ESI/MS of the oligosaccharides obtained from the total non-acid glycosphingolipid fraction from human medullary thyroid cancer had a number of molecular ions corresponding to oligosaccharides ranging from trisaccharides (detected as $\left[\mathrm{M}-\mathrm{H}^{+}\right]^{-}$ions at $m / z 503$ ) to hexasaccharides (detected as $\left[\mathrm{M}-\mathrm{H}^{+}\right]^{-}$ions at $m / z$ 998) (Figure 3A). All molecular ions were subjected to $\mathrm{MS}^{2}$ and the oligosaccharides thereby identified were given in the chromatogram (see Supplementary Figure S2 for interpretation formulas).

$\mathrm{MS}^{2}$ of the ion at $m / z 503$ gave prominent C-type fragment ions $\left(\mathrm{C}_{1}\right.$ at $m / z 179$ and $\mathrm{C}_{2}$ at $m / z$ 341) identifying a Hex-Hex-Hex sequence (data not shown). $\mathrm{A}^{2,4} \mathrm{~A}_{2}$ fragment ion 
at $m / z 221$ was present, which demonstrated that the penultimate Hex was 4-substituted.

Together this identified a globo trisaccharide (Gal $\alpha 4 \mathrm{Gal} \beta 4 \mathrm{Glc})$.

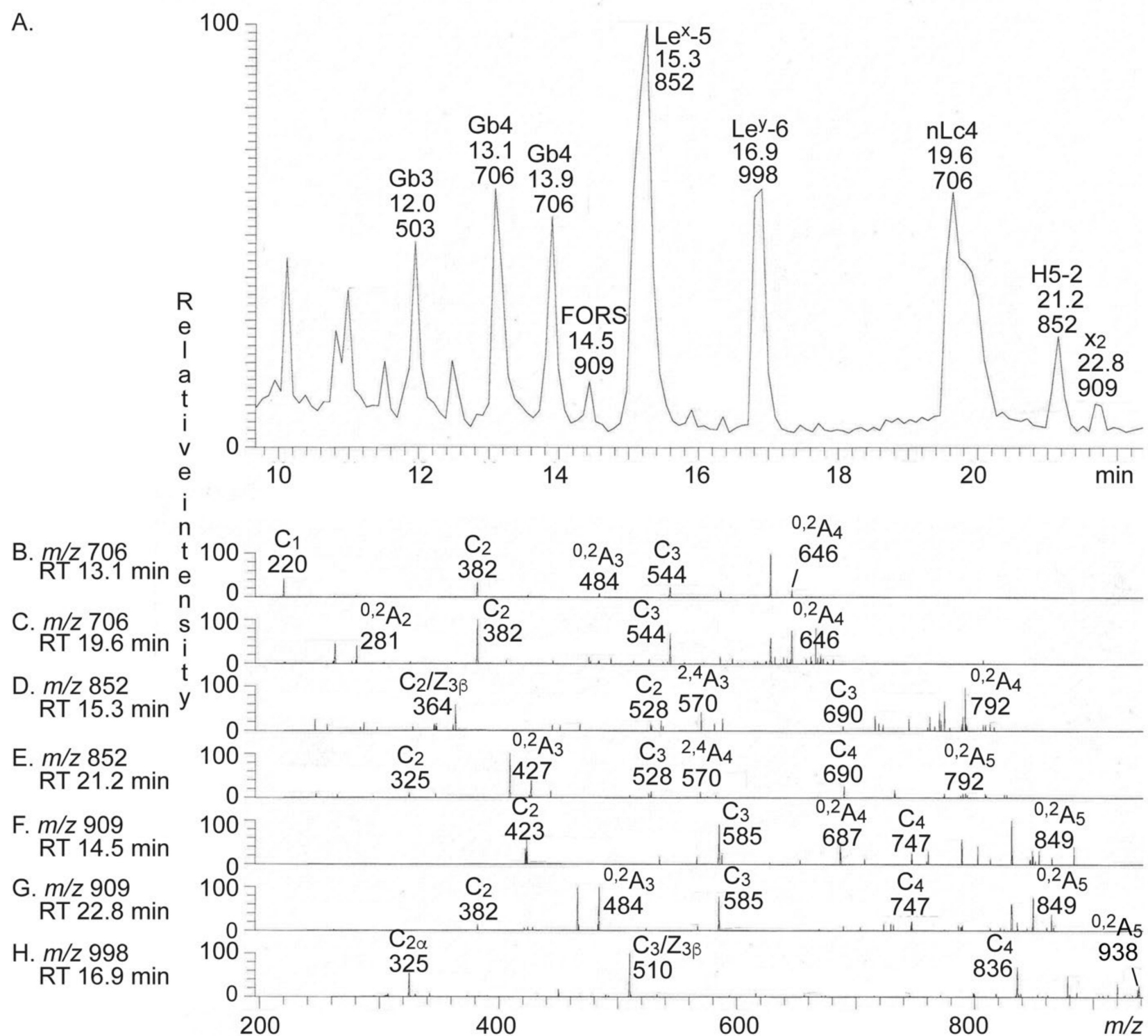

Figure 3. LC-ESI/MS of the oligosaccharides derived from the total non-acid glycosphingolipid fraction from human medullary thyroid cancer by hydrolysis with endoglycoceramidase II from Rhodococcus spp. The identification of oligosaccharides was based on their retention times, determined molecular masses, and subsequent $\mathrm{MS}^{2}$ sequencing. (A) Base peak chromatogram from LC-ESI/MS of the oligosaccharides obtained from the total non-acid glycosphingolipid fraction from human medullary thyroid cancer. (B) $\mathrm{MS}^{2}$ of the ion at $\mathrm{m} / \mathrm{z} 706$ at retention time $13.1 \mathrm{~min}$. (C) $\mathrm{MS}^{2}$ of the ion at $\mathrm{m} / \mathrm{z} 706$ at retention time $19.6 \mathrm{~min}$. (D) $\mathrm{MS}^{2}$ of the ion at $\mathrm{m} / \mathrm{z} 852$ at retention time $15.3 \mathrm{~min}$. (E) MS $\mathrm{MS}^{2}$ the ion at $\mathrm{m} / \mathrm{z} 852$ at retention time $21.2 \mathrm{~min}$. (F) $\mathrm{MS}^{2}$ of the ion at $\mathrm{m} / \mathrm{z} 909$ at retention time $14.5 \mathrm{~min}$. (G) $\mathrm{MS}^{2}$ of the ion at $\mathrm{m} / \mathrm{z} 909$ at retention time $22.8 \mathrm{~min}$. (H) $\mathrm{MS}^{2}$ of the ion at $\mathrm{m} / \mathrm{z} 998$ at retention time $16.9 \mathrm{~min}$. See Supplementary Figure S2 for interpretation formulas. The oligosaccharides identified in the chromatogram were: Gb3, Gal $\alpha 4 \mathrm{Gal} \beta 4 \mathrm{Glc}$; Gb4,

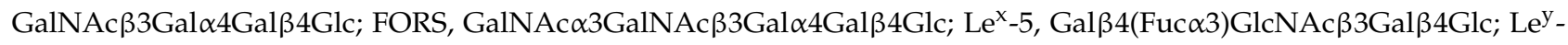

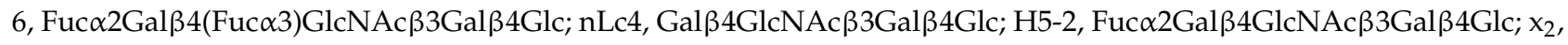
GalNAc $\beta 3 \mathrm{Gal} \beta 4 \mathrm{GlcNAc} \beta 3 \mathrm{Gal} \beta 4 \mathrm{Glc}$. RT, retention time.

The MS ${ }^{2}$ spectrum of the ion at $m / z 706$ at retention time 13.1-13.9 $\mathrm{min}$ (Figure $3 \mathrm{~B}$ ) had a C-type fragment ion series $\left(C_{1}\right.$ at $m / z 220, C_{2}$ at $m / z 382$, and $C_{3}$ at $\left.m / z 544\right)$, demonstrating a HexNAc-Hex-Hex-Hex sequence. The ${ }^{0,2} \mathrm{~A}_{3}$ fragment ion at $m / z 484$ demonstrated a 
4-substituted Hex $[15,16]$. Thereby, a globo tetrasaccharide (GalNAc $\beta 3$ Gal $\alpha 4$ Gal $\beta 4 G l c)$ was identified.

$\mathrm{MS}^{2}$ of the ion at $\mathrm{m} / \mathrm{z} 706$ at the retention time $19.6 \mathrm{~min}$ allowed identification of a neolacto tetrasaccharide (Gal $\beta 4 \mathrm{GlcNAc} \beta 3 \mathrm{Gal} \beta 4 \mathrm{Glc}$ ) (Figure $3 \mathrm{C}$ ). This was concluded from the C-type fragment ions $\left(C_{2}\right.$ at $m / z 382$ and $C_{3}$ at $m / z$ 544) identifying a Hex-HexNAc-HexHex sequence, along with the prominent ${ }^{0,2} \mathrm{~A}_{2}$ fragment ion at $m / z 281$ demonstrating a terminal Hex-HexNAc sequence with a 4-substituted HexNAc, i.e., a type 2 chain $[15,16]$.

The major ion in the base peak chromatogram was at $m / z 852$ eluting at $15.3 \mathrm{~min}$. MS ${ }^{2}$ of this ion gave an intense ion at $m / z 364$ (Figure 3D). This fragment ion is obtained by double glycosidic cleavage of the 3-linked branch $\left(\mathrm{C}_{2} / \mathrm{Z}_{3 \beta}\right)$, and characteristic for an internal 4-linked GlcNAc substituted with a Fuc at 3-position [16]. Together, with the $C_{2}$ ion at $m / z 528$ and the $C_{3}$ ion at $m / z 690$, a Le ${ }^{\mathrm{x}}$ pentasaccharide (Gal $\beta 4$ (Fuc $\alpha 3$ )GlcNAc $\beta 3$ Gal $\beta 4$ Glc) was thus identified.

The MS ${ }^{2}$ spectrum of the ion at $\mathrm{m} / \mathrm{z} 852$ eluting at $21.2 \mathrm{~min}$ was distinctly different (Figure 3E) and had a series of $C$ type fragment ions $\left(C_{2}\right.$ at $m / z 325, C_{3}$ at $m / z 528$, and $\mathrm{C}_{4}$ at $m / z$ 690), identifying a pentasaccharide with Fuc-Hex-HexNAc-Hex-Hex sequence. The ${ }^{0,2} \mathrm{~A}_{3}$ fragment ion at $m / z 427$ is characteristic for 4-substituted HexNAc, i.e., a type 2 carbohydrate chain $[15,16]$. This demonstrated an $\mathrm{H}$ type 2 pentasaccharide (Fuc $\alpha 2$ Gal $\beta 4$ GlcNAc $\beta 3$ Gal $\beta 4$ Glc).

The base peak chromatogram had two minor ions at $\mathrm{m} / \mathrm{z} 909$, eluting at $14.5 \mathrm{~min}$ and $22.8 \mathrm{~min}$, respectively. $\mathrm{MS}^{2}$ of the ion with retention time $14.5 \mathrm{~min}$ (Figure $3 \mathrm{~F}$ ) gave a $\mathrm{C}$ type fragment ion series $\left(C_{2}\right.$ at $m / z 423, C_{3}$ at $m / z 585$, and $C_{4}$ at $\left.m / z 747\right)$, identifying a pentasaccharide with HexNAc-HexNAc-Hex-Hex-Hex sequence. In addition, there was $\mathrm{a}^{0,2} \mathrm{~A}_{4}$ fragment ion at $m / z 687$ demonstrating 4-substitution of the internal Hex. This $\mathrm{MS}^{2}$ spectrum had a high similarity to the $\mathrm{MS}^{2}$ spectrum of the oligosaccharide released from the Forssman pentaosylceramide [17]. Thus, this demonstrated the presence of a Forssman (GalNAc $\alpha 3 \mathrm{GalNAc} \beta 3 \mathrm{Gal} \alpha 4 \mathrm{Gal} \beta 4 \mathrm{Glc}$ ) or a para-Forssman pentasaccharide (GalNAc $\beta 3$ GalNAc $\beta 3$ Gal $\alpha 4$ Gal $\beta 4 G l c)$.

A HexNAc-Hex-HexNAc-Hex-Hex carbohydrate sequence was identified by the series of $C$ type fragment ions $\left(C_{2}\right.$ at $m / z 382, C_{3}$ at $m / z 585$, and $C_{4}$ at $\left.m / z 747\right)$ obtained by $\mathrm{MS}^{2}$ of the ion at $\mathrm{m} / \mathrm{z} 909$ eluting at $22.8 \mathrm{~min}$ (Figure 3G). Here, 4-substitution of the internal HexNAc was demonstrated by the ${ }^{0,2} \mathrm{~A}_{3}$ fragment ion at $m / z$ 484. The $\mathrm{MS}^{2}$ spectrum was similar to the $\mathrm{MS}^{2}$ spectrum of the oligosaccharide released from the $\mathrm{x}_{2}$ pentaosylceramide [18] and together demonstrated an $x_{2}$ pentasaccharide (GalNAc $\beta 3$ Gal $\beta 4 G l c N A c \beta-$ 3Gal $\beta 4 \mathrm{Glc})$.

Finally, MS ${ }^{2}$ of the ion at $m / z 998$ demonstrated a Le ${ }^{y}$ hexasaccharide (Fuc $\alpha 2 G a l \beta 4-$ (Fuc $\alpha 3$ )GlcNAc $\beta 3$ Gal $\beta 4$ Glc) (Figure 3H). This conclusion was based on the prominent ion at $m / z 510$, which is obtained by double glycosidic cleavage of the 3-linked branch at $\mathrm{C}_{3}$ and $\mathrm{Z}_{3 \beta}$, and characteristic for an internal 4-linked GlcNAc substituted with a Fuc at 3-position [16], together with the series of $C$ type fragment ions $\left(C_{2 \alpha}\right.$ at $m / z 325$ and $C_{4}$ at $\mathrm{m} / \mathrm{z}$ 836).

The seven MS ${ }^{2}$ spectra all had ${ }^{0,2} \mathrm{~A}$ ions, which were derived from cross-ring cleavage of the 4-substituted Glc of the lactose unit at the reducing end.

Since the identification of a Forssman (or para-Forssman) pentasaccharide among the oligosaccharides derived from the non-acid glycosphingolipids from human medullary thyroid cancer was an unexpected finding, we next reduced the sample and again, analyzed by LC-ESI/MS. Here two minor ions at $\mathrm{m} / \mathrm{z} 911$ were present in the base peak chromatogram, eluting at $15.5 \mathrm{~min}$ and $20.9 \mathrm{~min}$, respectively. $\mathrm{MS}^{2}$ of the ion eluting at $15.5 \mathrm{~min}$ (Figure $4 \mathrm{~A}$ ) gave a series of $Y$ ions $\left(Y_{2}\right.$ at $m / z 343, Y_{3}$ at $m / z 505$ and $Y_{4}$ at $m / z$ 708) again demonstrating a HexNAc-HexNAc-Hex-Hex-Hex sequence. The HexNAc-HexNAc terminal was further confirmed by the $\mathrm{B}_{2}$ at $m / z 405$. 


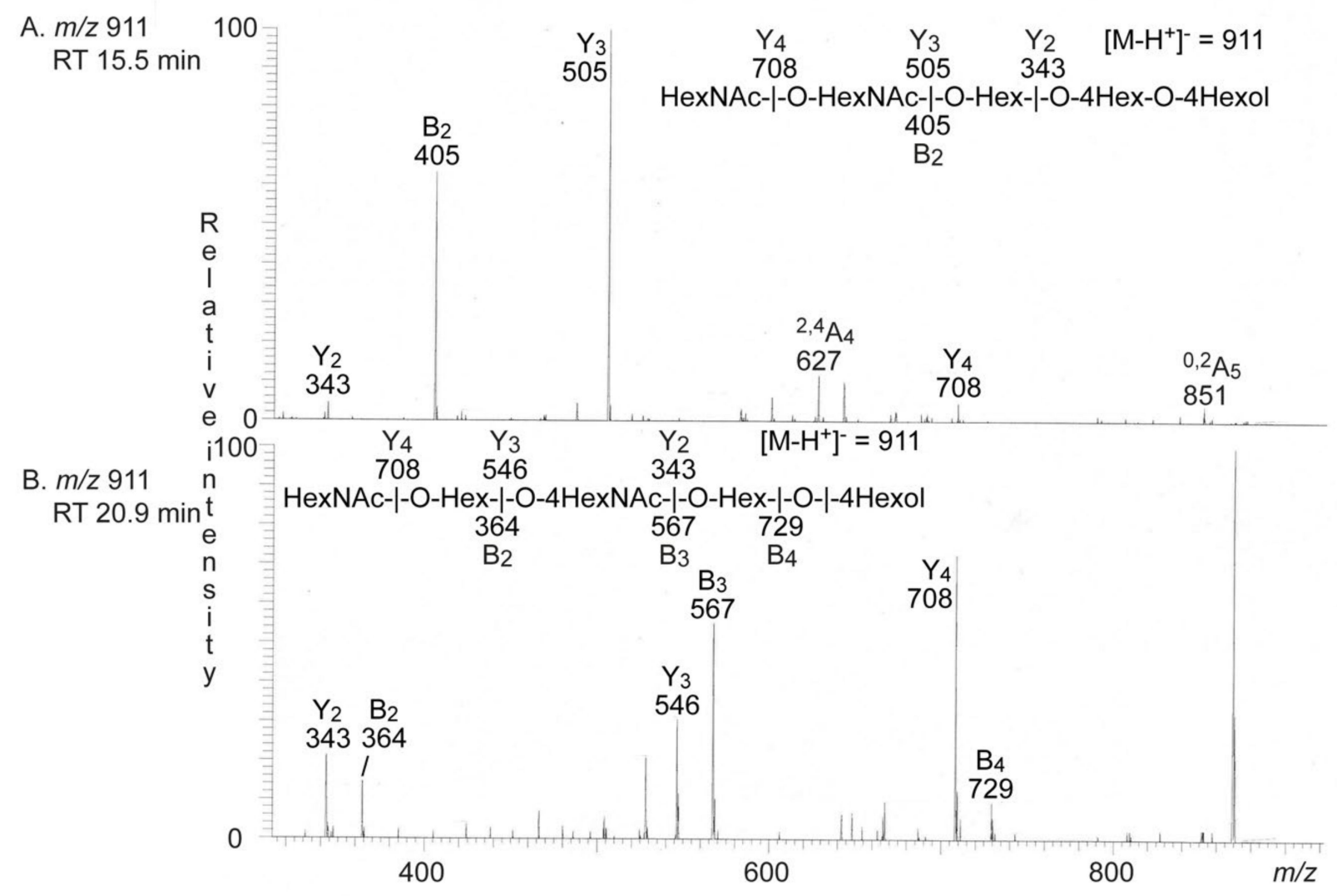

Figure 4. LC-ESI/MS of the reduced oligosaccharides obtained from the total non-acid glycosphingolipid fraction from human medullary thyroid cancer by hydrolysis with endoglycoceramidase II from Rhodococcus spp. The identification of the oligosaccharides was based on their retention times, determined molecular masses, and subsequent $\mathrm{MS}^{2}$ sequencing. (A) $\mathrm{MS}^{2}$ of the ion at $\mathrm{m} / \mathrm{z} 911$ at retention time $15.5 \mathrm{~min}$. (B) $\mathrm{MS}^{2}$ of the ion at $\mathrm{m} / \mathrm{z} 911$ at retention time $20.9 \mathrm{~min}$. The interpretation formulas show the deduced oligosaccharide sequences. RT, retention time.

The spectrum obtained by $\mathrm{MS}^{2}$ of the ion at $m / z 911$ at $20.9 \mathrm{~min}$ (Figure $4 \mathrm{~B}$ ) had a number of $Y$ ions $\left(Y_{2}\right.$ at $m / z 343, Y_{3}$ at $m / z 546$ and $Y_{4}$ at $\left.m / z 708\right)$, and $B$ ions $\left(B_{2}\right.$ at $m / z$ 364, $\mathbf{B}_{3}$ at $m / z 567$ and $\mathbf{B}_{4}$ at $\left.m / z 729\right)$, in line with a HexNAc-Hex-HexNAc-Hex-Hex sequence.

$\alpha$-N-Acetylgalactosaminidase Hydrolysis

Thereafter, the oligosaccharides from non-acid glycosphingolipids fraction were digested with $\alpha-N$-acetylgalactosaminidase to determine if the oligosaccharide with HexNAcHexNAc-Hex-4Hex-4Hex sequence was derived from a Forssman (GalNAc $\alpha 3$ GalNAc $\beta$ $3 \mathrm{Gal} \alpha 4 \mathrm{Gal} \beta 4 \mathrm{Glc} \beta 1 \mathrm{Cer}$ ) or a para-Forssman (GalNAc $\beta 3 \mathrm{GalNAc} \beta 3 \mathrm{Gal} \alpha 4 \mathrm{Gal} \beta 4 \mathrm{Glc} \beta 1 \mathrm{Cer}$ ) glycosphingolipid. The untreated oligosaccharides and the resulting oligosaccharides from the enzymatic digestions were analyzed by LC-ESI/MS (Supplementary Figure S3). Upon treatment with $\alpha-N$-acetylgalactosaminidase the molecular ion at $\mathrm{m} / \mathrm{z} 909$ disappeared, confirming an $\alpha$-linked terminal GalNAc as in the Forssman oligosaccharide (Supplementary Figure S3B). The other molecular ions were not affected, except for the molecular ion at $\mathrm{m} / \mathrm{z}$ 1055 (blood group A type 2 hexasaccharide; GalNAc $\alpha 3$ (Fuc $\alpha 2)$ Gal $\beta 4 \mathrm{GlcNAc} \beta 3 \mathrm{Gal} \beta 4 \mathrm{Glc}$; see below), which also disappeared upon $\alpha-N$-acetylgalactosaminidase hydrolysis.

\subsubsection{Separation of the Non-Acid Glycosphingolipids}

After these studies, the total non-acid glycosphingolipid fraction from human MTC was separated by chromatography on an latrobeads column, in order to enrich the slowmigrating glycosphingolipids. This gave four subfractions, denoted fractions T1 to T4. The glycosphingolipids in fraction T1 migrated in the monoglycosylceramide region, fraction T2 had compounds migrating as di- to tetraglycosylceramides, fraction T3 mainly tetragly- 
cosylceramides, and fraction $\mathrm{T} 4$ had tetraglycosylceramides and more slow-migrating glycosphingolipids (Figure 5A, lanes 1-4)
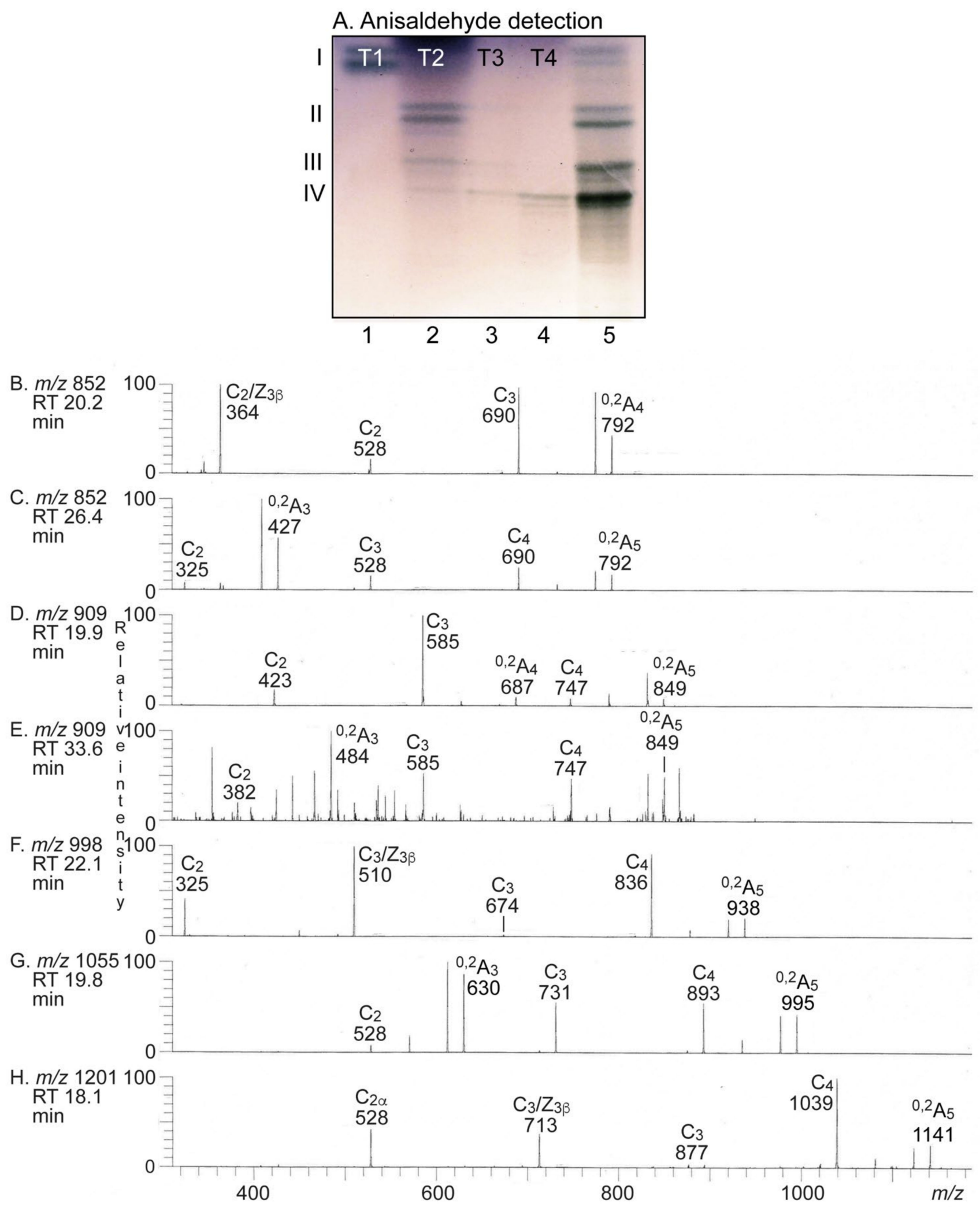

Figure 5. (A) Thin-layer chromatography of the non-acid glycosphingolipid subfractions from human medullary thyroid cancer. Thin-layer chromatogram after detection with anisaldehyde. The lanes were: lane 1, glycosphingolipid subfraction T1 from human medullary thyroid cancer, $4 \mu \mathrm{g}$; lane 2, subfraction T2, $4 \mu \mathrm{g}$; lane 3, subfraction T3, $4 \mu \mathrm{g}$; lane 4, subfraction 4, 
$4 \mu \mathrm{g}$; lane 5, reference non-acid glycosphingolipids from human blood group AB erythrocytes, $40 \mu \mathrm{g}$. The Roman numbers to the left of the chromatogram indicate the approximate number of carbohydrate units in the bands. (B-H) LC-ESI/MS of the oligosaccharides obtained from fraction T4 from human medullary thyroid cancer by hydrolysis with endoglycoceramidase II from Rhodococcus spp. The identification of the oligosaccharides was based on their retention times, determined molecular masses, and subsequent $\mathrm{MS}^{2}$ sequencing. (B) $\mathrm{MS}^{2}$ of the ion at $\mathrm{m} / \mathrm{z} 852$ at retention time $20.2 \mathrm{~min}$. (C) MS $\mathrm{M}^{2}$ of the ion at $m / z 852$ at retention time $26.4 \mathrm{~min}$. (D) $\mathrm{MS}^{2}$ of the ion at $\mathrm{m} / \mathrm{z} 909$ at retention time $19.0 \mathrm{~min}$. (E) $\mathrm{MS}^{2}$ of the ion at $m / z$ 909 at retention time $33.6 \mathrm{~min}$. (F) MS $\mathrm{MS}^{2}$ of the ion at $\mathrm{m} / z 998$ at retention time $22.1 \mathrm{~min}$. (G) $\mathrm{MS}^{2}$ of the ion at $\mathrm{m} / z 1055$ at retention time $19.8 \mathrm{~min}$. (H) $\mathrm{MS}^{2}$ of the ion at $\mathrm{m} / \mathrm{z} 1201$ at retention time $18.1 \mathrm{~min}$. See Supplementary Figure S2 for interpretation formulas. The oligosaccharides identified were: Le ${ }^{x}-5$, Gal $\beta 4$ (Fuc $\alpha 3$ )GlcNAc $\beta 3$ Gal $\beta 4$ Glc; H5-2, Fuc $\alpha 2$ Gal $\beta 4$ GlcNAc $\beta 3$ Gal $\beta 4 G l c ;$ FORS, GalNAc $\alpha 3 G a l N A c \beta 3 G a l \alpha 4 G a l \beta 4 G l c ; x_{2}$, GalNAc $\beta 3 G a l \beta 4 G l c N A c \beta 3 G a l \beta 4 G l c$; Le $^{\mathrm{y}}$-6, Fuc $\alpha 2$ Gal $\beta 4$ (Fuc $\alpha 3$ )GlcNAc $\beta 3$ Gal $\beta 4$ Glc; A6-2, GalNAc $\alpha 3$ (Fuc $\left.\alpha 2\right)$ Gal $\beta 4$ GlcNAc $\beta 3$ Gal $\beta$ Glc; A7-2, GalNAc $\alpha 3$ (Fuc $\alpha 2$ )Gal $\beta 4$ (Fuc $\alpha 3)$ GlcNAc $\beta 3$ Gal $\beta 4$ Glc. RT, retention time.

\subsubsection{LC-ESI/MS of Fraction T-1}

The native fraction T-1 was analyzed by LC-ESI/MS using a polyamine column (Supplementary Figure S4). Thereby, mono- and dihexosylceramides with sphingosine, and both hydroxy and non-hydroxy fatty acids with 16 and 24 carbon atoms, were identified.

\subsubsection{LC-ESI/MS of Fractions T2-T4}

Fractions T2, T3 and T4 were hydrolyzed with endoglycoceramidase II and the oligosaccharides obtained were characterized by LC-ESI/MS. The globo trisaccharide, globo tetrasaccharide, and neolacto tetrasaccharide were thereby identified, as above, in fractions T2 and T3 (data not shown). Fraction T3 also had the $\mathrm{Le}^{\mathrm{x}}$ pentasaccharide and Le $\mathrm{e}^{\mathrm{y}}$ hexasaccharide.

The $\mathrm{Le}^{\mathrm{x}}, \mathrm{H}$ type 2, Forssman and $\mathrm{x}_{2}$ pentasaccharides, and the Le $\mathrm{e}^{\mathrm{y}}$ hexasaccharide were characterized as described above by LC-ESI/MS of the oligosaccharides obtained from fraction T4 (Figure 5B-F). The base peak chromatogram also had two novel molecular ions at $m / z 1055$ and $m / z$ 1201, respectively (Figure 5A). MS ${ }^{2}$ of the ion at $m / z 1055$ gave a series of C-type fragment ions $\left(C_{2}\right.$ at $m / z 528, C_{3}$ at $m / z 731$, and $C_{4}$ at $m / z$ 893), which indicated a HexNAc-(Fuc)Hex-HexNAc-Hex-Hex sequence (Figure $5 \mathrm{G}$ ). The ${ }^{0,2} \mathrm{~A}_{3}$ fragment ion at $m / z 630$ demonstrated a type 2 core chain. Thus, a blood group A type 2 hexasaccharide (GalNAc $\alpha 3$ (Fuc $\alpha 2)$ Gal $\beta 4$ GlcNAc $\beta 3$ Gal $\beta 4$ Glc) was identified.

$\mathrm{MS}^{2}$ of the molecular ion at $m / z 1201$ (Figure $5 \mathrm{H}$ ) gave a series of C-type fragment ions $\left(C_{2}\right.$ at $m / z 528, C_{3}$ at $m / z 877$, and $C_{4}$ at $\left.m / z 1039\right)$, which demonstrated a HexNAc(Fuc-)Hex-(Fuc-)HexNAc-Hex-Hex sequence. The spectrum also had a fragment ion at $m / z 713$, which is obtained by double glycosidic cleavage of the 3-linked branch $\left(\mathrm{C}_{3} / \mathrm{Z}_{3 \beta}\right)$, and thus characteristic for an internal 4-linked GlcNAc substituted with a Fuc at 3position [19]. Together, this identified a blood group A type 2/ALe ${ }^{\mathrm{y}}$ heptasaccharide (GalNAc $\alpha 3$ (Fuc $\alpha 2)$ Gal $\beta 4$ (Fuc $\alpha 3)$ GlcNAc $\beta 3$ Gal $\beta 4 G l c)$.

In a final attempt to identify minor complex compounds, we re-analyzed the oligosaccharides at $m / z$ 1000-2000. Therefore, a minor molecular ion at $m / z 1016$ (reduced $\mathrm{m} / \mathrm{z} 1014$ ) was detected when analyzing the reduced oligosaccharides from fractions T4 (Figure 6A). $\mathrm{MS}^{2}$ of this ion (Figure 6B) gave series with $\mathrm{B}$ and $\mathrm{C}$ type fragment ions $\left(\mathrm{C}_{2}\right.$ at $\mathrm{m} / z$ 325, $\mathrm{B}_{3}$ at $m / z 510, \mathrm{C}_{3}$ at $m / z 528, \mathrm{~B}_{4}$ at $m / z 672, \mathrm{C}_{4}$ at $m / z 690, \mathrm{~B}_{5}$ at $m / z$ 834, and $\mathrm{C}_{5}$ at $m / z$ 852) and a $\mathrm{Y}$ type ion series $\left(\mathrm{Y}_{2}\right.$ at $m / z 343, \mathrm{Y}_{3}$ at $m / z 505, \mathrm{Y}_{4}$ at $m / z 708$, and $\mathrm{Y}_{5}$ at $m / z$ 870), establishing a Fuc-Hex-HexNAc-Hex-Hex-Hex carbohydrate sequence. Thus, the Globo $\mathrm{H}$ oligosaccharide (Fuc $\alpha 2 \mathrm{Gal} \beta 3 \mathrm{GalNAc} \beta 3 \mathrm{Gal} \alpha 4 \mathrm{Gal} \beta 4 \mathrm{Glc}$ ) was tentatively identified. 


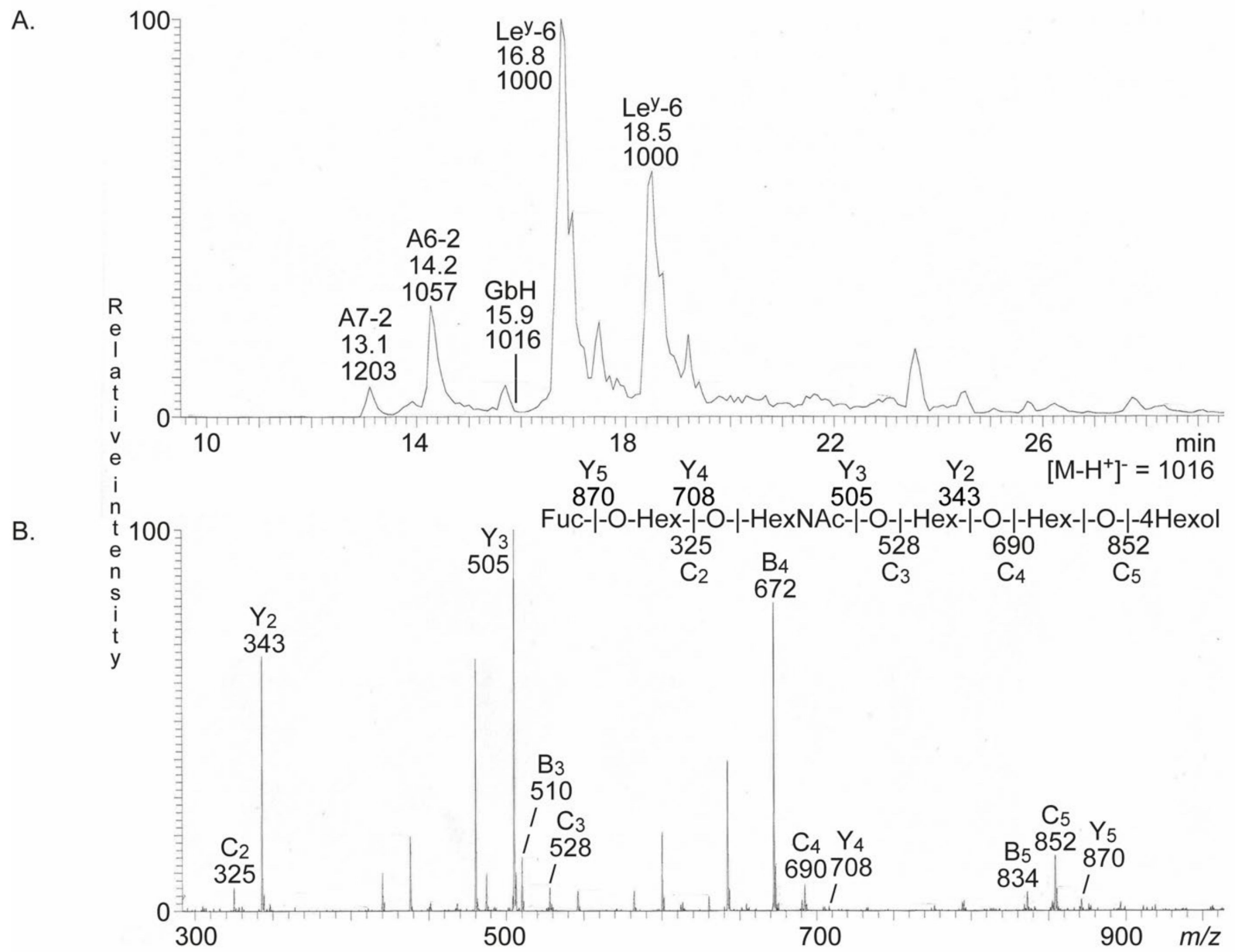

Figure 6. LC-ESI/MS ( $m / z$ 1000-2000) of the reduced oligosaccharides obtained from fraction T2-4 from human medullary thyroid cancer by hydrolysis with endoglycoceramidase II from Rhodococcus spp. The identification of the oligosaccharides was based on their retention times, determined molecular masses, and subsequent $\mathrm{MS}^{2}$ sequencing. (A) Base peak chromatogram from LC-ESI/MS of the reduced oligosaccharides obtained from fraction T4. (B) MS ${ }^{2}$ of the ion at $\mathrm{m} / \mathrm{z} 1016$ at retention time $15.9 \mathrm{~min}$. The interpretation formula shows the deduced oligosaccharide sequence. The oligosaccharides identified in the chromatogram were: A7-2, GalNAc $\alpha 3$ (Fuc $\alpha 2)$ Gal $\beta 4$ (Fuc $\alpha 3$ )GlcNAc $\beta 3$ Gal $\beta 4$ Glc; A6-2,

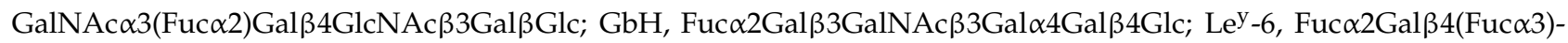
GlcNAc $\beta 3$ Gal $\beta 4$ Glc.

2.3.5. Binding of Carbohydrate Recognizing Ligands to the Non-Acid Glycosphingolipids

In order to validate the structural information obtained by mass spectrometry, the binding of carbohydrate binding ligands to fractions T2-T4 was next examined in a chromatogram binding assay (Figure 7). Thereby, a distinct interaction of the GalNAc $\alpha$ binding lectin from $H$. pomatia [20], and the anti-Forssman monoclonal antibodies, to fraction $\mathrm{T} 4$ was obtained (Figure 7B,C, lane 3), confirming the presence of the Forssman glycosphingolipid. The existence of the $\mathrm{H}$ type 2 pentaosylceramide in fraction $\mathrm{T} 4$ was confirmed by the binding of anti-H type 2 monoclonal antibodies (Figure 7D, lane 3), and these antibodies also marked the $\mathrm{H}$ type 2 heptaosylceramide. The presence of glycosphingolipids with blood group $\mathrm{Le}^{\mathrm{x}}$, $\mathrm{Le}^{\mathrm{y}}$, Globo $\mathrm{H}$ and A determinants in fraction $\mathrm{T} 4$ was confirmed by the binding of monoclonal antibodies (Figure 7E-H, lane 3). The antibodies against blood group $\mathrm{Le}^{\mathrm{x}}, \mathrm{Le}^{\mathrm{y}}$, and A determinants also recognized slow-migrating compounds in fraction $\mathrm{T} 4$, indicating the presence of complex glycosphingolipids carrying these determinants. 
A. Anisaldehyde detection

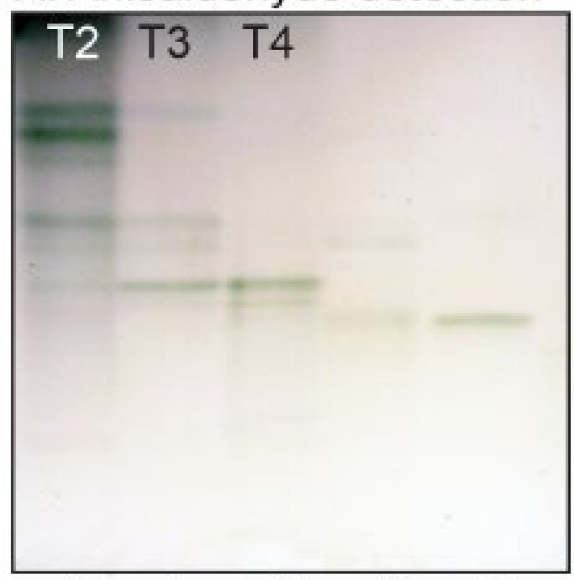

$\begin{array}{lllll}1 & 2 & 3 & 4 & 5\end{array}$

\section{Anti-H type 2}

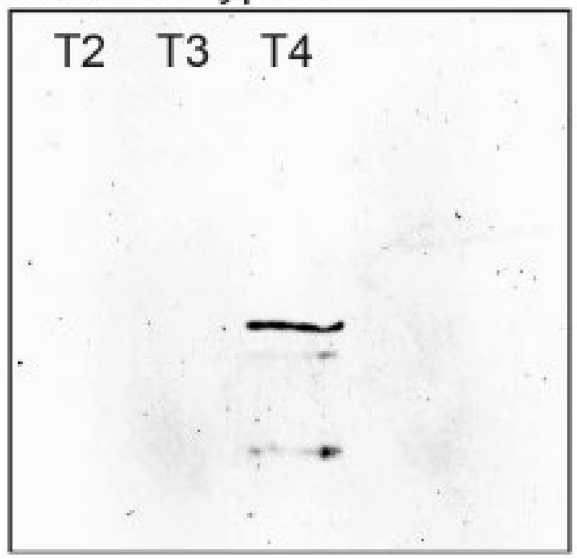

$\begin{array}{lllll}1 & 2 & 3 & 4 & 5\end{array}$
B. Anti-Forssman

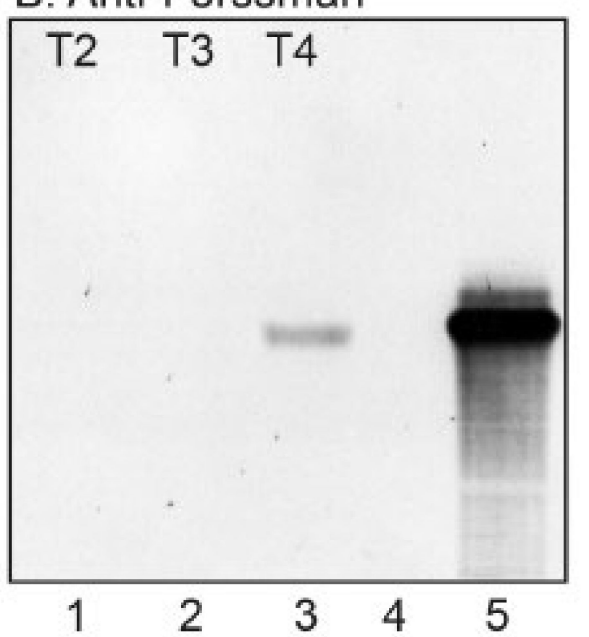

E. Anti-Le ${ }^{\mathrm{x}}$

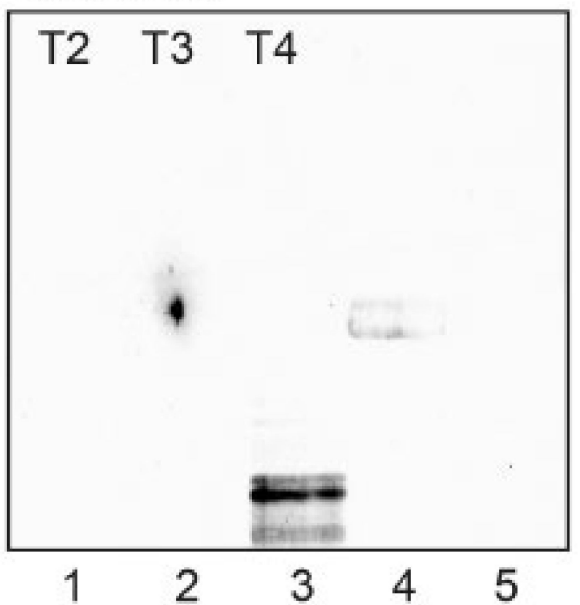

C. H. pomatia lectin

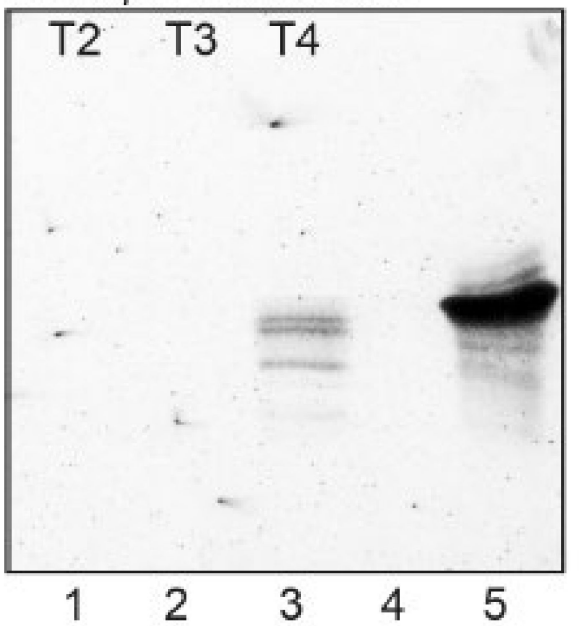

F. Anti-Le ${ }^{y}$

$\begin{array}{lll}\text { T2 } & \text { T3 } & \text { T4 }\end{array}$

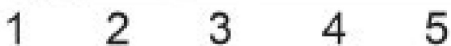

G. Anti-GbH

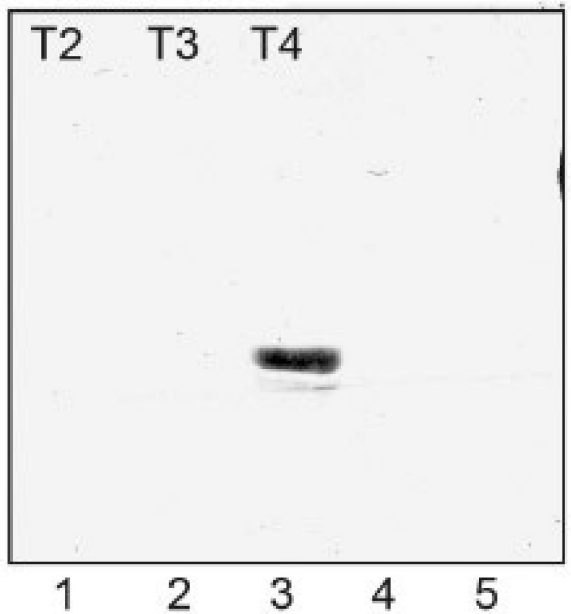

H. Anti-A

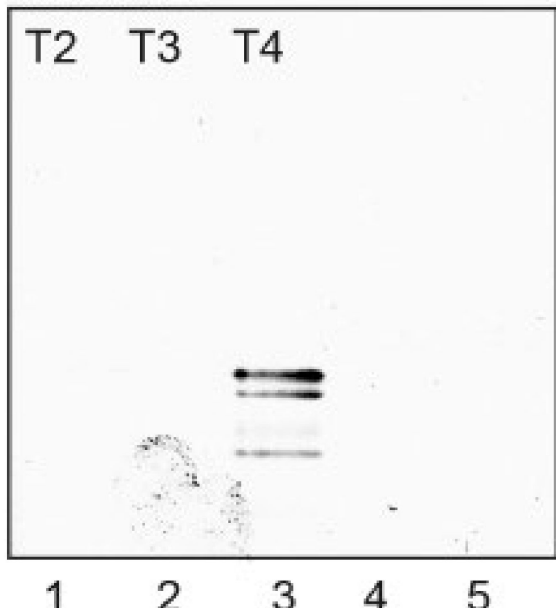

Figure 7. Binding of lectins and antibodies to the non-acid glycosphingolipid subfractions from human medullary thyroid cancer. Thin-layer chromatogram after detection with anisaldehyde (A), and autoradiograms obtained by binding of monoclonal anti-Forssman antibodies (B), GalNAc $\alpha$-binding H. pomatia lectin (C), monoclonal anti-H type 2 antibodies (D), monoclonal anti-Le $\mathrm{e}^{\mathrm{x}}$ antibodies $(\mathbf{E})$, monoclonal anti-Le ${ }^{\mathrm{y}}$ antibodies $(\mathbf{F})$, monoclonal anti-globo $\mathrm{H}$ antibodies $(\mathbf{G})$, and monoclonal 
anti-A antibodies $(\mathbf{H})$. The lanes were: lane 1, glycosphingolipid subfraction T2 from human medullary thyroid cancer, $4 \mu \mathrm{g}$; lane 2, subfraction $\mathrm{T} 3,4 \mu \mathrm{g}$; lane 3, subfraction T4, $4 \mu \mathrm{g}$; lane 4, reference neolactotetraosylceramide

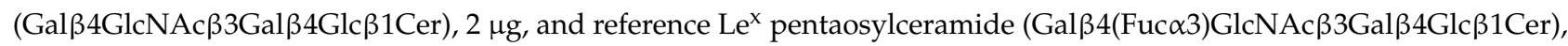
$2 \mu \mathrm{g}$; lane 5, reference Forssman pentaosylceramide (GalNAc $\alpha 3$ GalNAc $\beta 3$ Gal $\alpha 4$ Gal $\beta 4 \mathrm{Glc} \beta 1 \mathrm{Cer}), 4 \mu \mathrm{g}$.

The oligosaccharides derived from the non-acid glycosphingolipids of human medullary thyroid cancer are summarized in Table 2.

Table 2. Glycosphingolipid-derived oligosaccharides from the non-acid fractions from human medullary thyroid cancer identified by LC-ESI/MS.

\begin{tabular}{|c|c|c|}
\hline$m / z$ & Trivial Name & Structure \\
\hline 503 & Globotri (Gb3) & Gal $\alpha 4 \mathrm{Gal} \beta 4 \mathrm{Glc}$ \\
\hline 706 & Neolactotetra (nLc4) & Gal $\beta 4$ GlcNAc $\beta 3$ Gal $\beta 4$ Glc \\
\hline 706 & Globotetra (Gb4) & GalNAc $\beta 3$ Gal $\alpha 4 \mathrm{Gal} \beta 4 \mathrm{Glc}$ \\
\hline 909 & Forssman & GalNAc $\alpha 3$ GalNAc $\beta 3$ Gal $\alpha 4$ Gal $\beta 4$ Glc \\
\hline 909 & $\mathrm{x}_{2}$ penta $\left(\mathrm{x}_{2}\right)$ & GalNAc $\beta 3$ Gal $\beta 4$ GlcNAc $\beta 3$ Gal $\beta 4$ Glc \\
\hline 852 & H type 2 penta (H5-2) & Fuc $\alpha 2$ Gal $\beta 4$ GlcNAc $\beta 3$ Gal $\beta 4$ Glc \\
\hline 852 & $\operatorname{Le}^{\mathrm{x}}$ penta $\left(\operatorname{Le}^{\mathrm{x}}-5\right)$ & Gal $\beta 4$ (Fuc $\alpha 3)$ GlcNAc $\beta 3$ Gal $\beta 4$ Glc \\
\hline 998 & $\mathrm{Le}^{\mathrm{y}}$ hexa $\left(\mathrm{Le}^{\mathrm{y}}-6\right)$ & Fuc $\alpha 2$ Gal $\beta 4($ Fuc $\alpha 3)$ GlcNAc $\beta 3$ Gal $\beta 4$ Glc \\
\hline $1016(\mathrm{red}) *$ & Globo H & Fuc $\alpha 2$ Gal $\beta 3$ GalNAc $\beta 3$ Gal $\alpha 4$ Gal $\beta 4$ Glc \\
\hline 1055 & A hexa type 2 (A6-2) & GalNAc $\alpha 3($ Fuc $\alpha 2)$ Gal $\beta 4$ GlcNAc $\beta 3$ Gal $\beta 4$ Glc \\
\hline 1201 & A hepta type $2(\mathrm{~A} 7-2)$ & GalNAc $\alpha 3($ Fuc $\alpha 2)$ Gal $\beta 4(F u c \alpha 3)$ GlcNAc $\beta 3$ Gal $\beta 4$ Glc \\
\hline
\end{tabular}

${ }^{*}$ Reduced.

\subsection{Immunohistochemistry}

Immunohistochemical analysis demonstrated expression of blood group A antigens in the MTC samples collected from patients with blood group A $(n=2)$ (Figure 8A), and no presence in the blood group $\mathrm{B}(n=1)$ and $\mathrm{O}(n=3)$ individuals. An evident blood group A expression was seen in the vascular and supportive tissue, and in some of the tumor cells. All MTC cells extensively expressed the Le $\mathrm{e}^{\mathrm{y}}$ determinant (Figure 8B), while no significant positive staining was seen in the supportive tissue or in the non-neoplastic follicular thyroid tissue (Figure $8 \mathrm{C}$ ). The extent and intensity of the noted positive staining

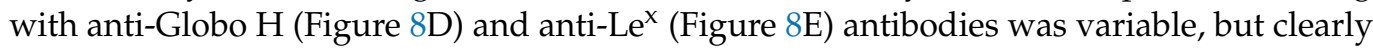
present, in all samples demonstrating a subpopulation of cells with antigen expression. One individual expressed the Forssman antigens in the tumor and blood cells (Figure 8F), all other samples $(n=8)$ showed no positive staining with the anti-Forssman antibody. 

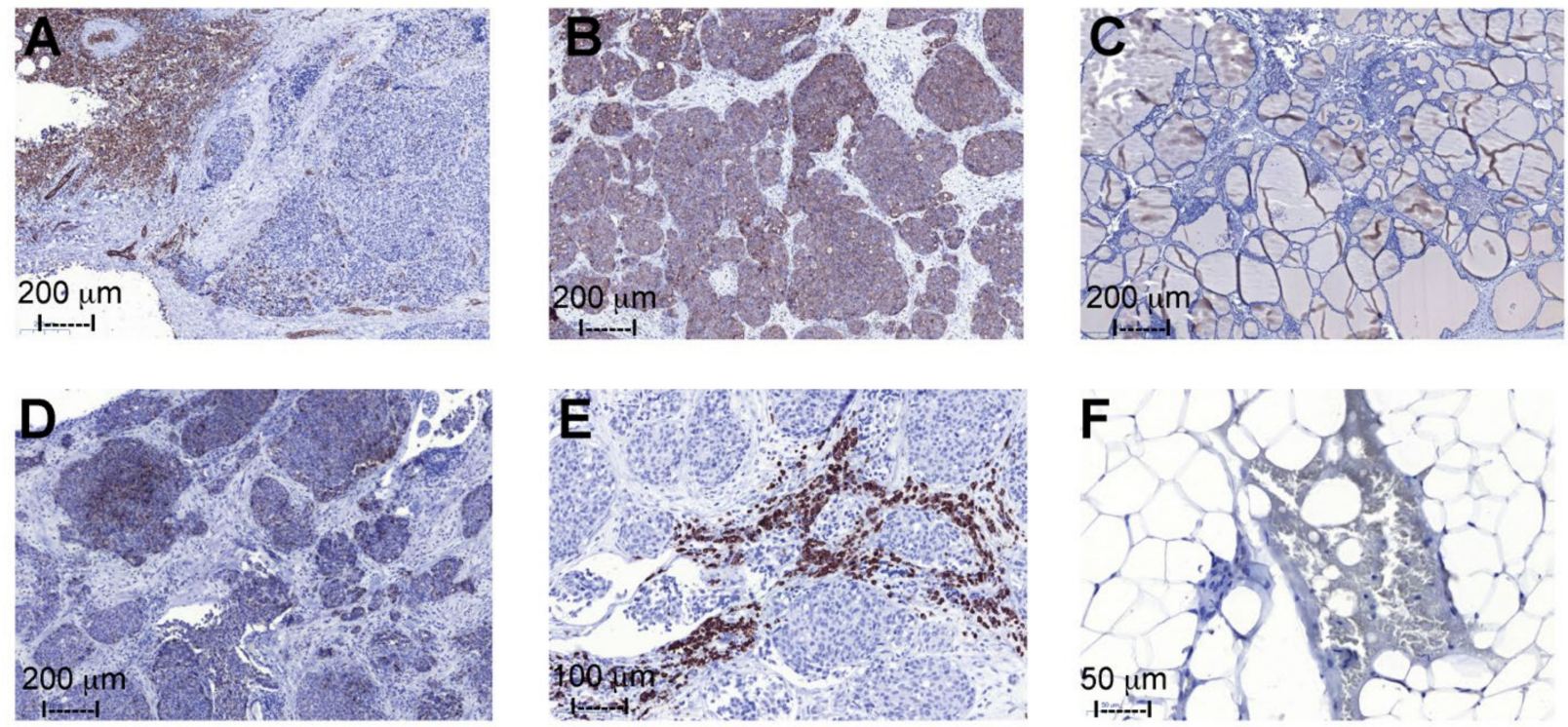

Figure 8. Immunohistochemical evaluation of medullary thyroid cancer (A,B,D-F) and non-neoplastic follicular thyroid tissue samples (C). (A) shows a positive staining with the anti-A antibody in the supportive tissue and in some of the tumor cells, (B) shows an extensive expression of Le ${ }^{\mathrm{y}}$ antigens in the medullary thyroid cancer cells, (C) shows no significant staining of benign/non-neoplastic thyroid tissue with the anti-Le ${ }^{\mathrm{y}}$ antibody, (D) shows the expression of the Globo $\mathrm{H}$ antigen in a subpopulation of the tumor cells, (E) shows a positive staining with the anti-Le ${ }^{\mathrm{x}}$ antibody in a portion of the tumor cells, and (F) shows the expression of Forssman antigens in the tumor and blood cells of one individual with blood group B.

\section{Discussion}

In this study, we have obtained a high resolution of the glycosphingolipids present in human medullary carcinomas of the thyroid. This was due to a large amount of starting material (wet weight $20 \mathrm{~g} /$ dry weight $5.4 \mathrm{~g}$ ) allowing several chromatographic purification steps, and separation of the glycosphingolipids into total acid and non-acid fractions. The glycosphingolipid material obtained also permitted us to obtain partly purified glycosphingolipid subfractions, which made it possible to identify minor compounds using a combination of mass spectrometry and binding of carbohydrate recognizing ligands.

The GD3 ganglioside was the acid major glycosphingolipid, as previously reported by Mariano et al. [12]. The acid fraction also had sulfatide, and the gangliosides GM3 and GD1a (see Table 1 for glycosphingolipid structures). The amount of acid glycosphingolipids in the medullary thyroid cancers was higher than in the normal thyroid glands. This is in agreement with previous lectin immunohistochemistry studies, which showed an increased sialylation in thyroid cancers, albeit mainly in papillary and follicular carcinomas [21]. However, other studies have reported that malignant transformation in the thyroid gland leads to decreased sialylation $[22,23]$.

A weak expression of the sialyl-Le ${ }^{\mathrm{a}}$ antigen (CA19:9 ligand) in a few MTC has been reported [22,23]. In our study, we did not find sialyl-Le ${ }^{a}$ by mass spectrometry, and no binding of the 19:9 antibody to the acid glycosphingolipids was obtained.

For the characterization of the non-acid glycosphingolipids, we used endoglycoceramidase II from Rhodococcus sp., and the oligosaccharides thereby released were analyzed by LC/MS. Here, it should be noted that the relative intensities of the molecular ions in the chromatograms do not mirror the relative abundance of the glycosphingolipids in the samples, since the hydrolytic capacity of endoglycoceramidase II is somewhat restricted, certain glycosphingolipods, e.g., globo-series glycosphingolipids, are relatively resistant to this enzyme [24,25].

Among the non-acid glycosphingolipids, the majority of the characterized complex compounds had type 2 (Gal $\beta 4 \mathrm{GlcNAc}$ ) core chains, i.e., the neolactotetraosylceramide, the $\mathrm{Le}^{\mathrm{x}}, \mathrm{H}$ type 2 and $\mathrm{x}_{2}$ pentaosylceramides, the $\mathrm{Le}^{\mathrm{y}}$ and $\mathrm{A}$ type 2 hexaosylceramides, 
and the A type 2 heptaosylceramide. In addition, there were compounds with globo (Gal $\alpha$ Gal $\beta 4$ Glc) core, i.e., globotriaosylceramide, globotetraosylceramide, the Forssman pentaosylceramide, and the globo $\mathrm{H}$ hexaosylceramide (see Table 2 for oligosaccharide structures). No compounds with type 1 (Gal $\beta 3 \mathrm{GlcNAc}$ ) or ganglio (Gal $\beta 3 \mathrm{GalNAc})$ core chains were characterized.

These findings are supported by the outcome of the immunohistochemistry analysis, which showed expression of blood group A and Le ${ }^{\mathrm{x}}$ determinants in a portion of the MTC cells, and extensive expression of the $\mathrm{Le}^{\mathrm{y}}$ antigens in all MTC samples. However, only five patients were studied here, so further immunohistochemistry analysis should be carried out. The Le ${ }^{\mathrm{y}}$ antigen is upregulated on many types of cancer, e.g., lung, breast, colorectal, ovarian, and prostate cancers, and is a promising target for gene-modified $\mathrm{T}$ cells and antibody targeting reviewed in [8]. Thus, $\mathrm{Le}^{\mathrm{y}}$ may potentially be used in the case of MTC as a target for the development of future therapeutic and diagnostic applications.

Globo $\mathrm{H}$ is a prevalent cancer-associated glycosphingolipid and is overexpressed in many cancers of epithelial origins (e.g., breast, ovary, uterus, prostate, lung, colon, and liver cancers) [26]. Currently, there are several ongoing clinical trials on immunotherapies targeting globo $\mathrm{H}$. Immunohistochemistry studies have demonstrated the presence of Globo $\mathrm{H}$ in 33\% of MTCs, but not in normal thyroidea or benign thyroid lesions [27]. In our study, the Globo $\mathrm{H}$ hexaosylceramide was minor, and by mass spectrometry, it could only be characterized by a targeted search. Immunohistochemical evaluation of nine MTC samples showed a subpopulation, of variable quantity, that clearly expressed Globo $\mathrm{H}$ in all of the examined individuals. Hence, it would be of great interest to investigate the outcome of immunotherapy against Globo H in MTC patients.

The characterization of the Forssman pentaosylceramide among the non-acid glycosphingolipids from human medullary thyroid cancer was an unexpected finding. Further investigation with immunohistochemistry of samples from five of the 14 individuals included in the glycosphingolipid preparation identified one individual with blood group B, and diagnosed an individual with multiple endocrine neoplasia type 2B (MEN2B) expressing Forssman antigens. However, the sample from this individual was a small lymph node with a high content of adipocytes and a limited amount of tumor tissue.

Until recently, humans were considered to be a Forssman negative species since the Forssman synthase gene in humans is inactive. However, the identification of the Forssman glycolipid antigen on erythrocytes of the rare individuals of the $A_{\text {pae }}$ phenotype led to the recognition of the FORS system as a novel blood group system [17]. In these $A_{\text {pae }}$ individuals, the gene coding for the Forssman synthase (GBGT1) encodes an arginine to glutamine change at residue 296, which gives reactivation of the human Forssman synthase. FORS is, however, a rare blood group system, and some individuals have naturally occurring anti-Forssman (anti-FORS1) antibodies in plasma. However, the frequency of these anti-FORS1 antibodies is still unclear [28,29].

A role for Forssman as a tumor-associated carbohydrate antigen has not yet been established. During the 1970ies-1980ies the presence of the Forssman glycosphingolipid both in normal human tissues as kidney and gastrointestinal mucosa [30,31], and in some human cancers as e.g., gastric, lung and liver cancer, was reported (reviewed in [32]). However, if this was the product of the Forssman synthase is not known. Furthermore, some of these studies used polyclonal sera for detection of Forssman, and thus crossreactions with other glycans are possible.

More recently it was demonstrated that vaccination with the terminal disaccharide of the Forssman antigen (GalNAc $\alpha 3$ GalNAc $\beta$ ) induce antibody responses to the Forssman disaccharide, and those responses correlate with long-term survival of vaccinated patients with prostate cancer [33].

The finding of Forssman expression in a patient with MEN2B is an intriguing combination since both are very rare events in the clinic. We are now investigating the molecular background, and the potential association, which will be reported separately. 
The expression of blood group antigens in MTC has been investigated by immunohistochemistry studies using monoclonal antibodies [34-36]. These studies demonstrated that blood group antigens were not expressed in normal follicular or C-cells, but were expressed to a various extent in medullary thyroid cancers, and were expressed more frequently in malignant than in benign neoplasms. The occurrence blood group antigens with type 1 core chain in medullary carcinomas of the thyroid has been demonstrated [34]. These findings should reflect binding to glycoproteins since no type 1 core glycosphingolipids were characterized in our current study. However, it should be kept in mind that monoclonal antibodies against carbohydrate antigens often are highly cross-reactive [37], and may give false-positive results leading to an overestimation of antigen expression levels. Thus, verification of the results with one or more independent analytical methods is needed.

No tumor specific biomarkers are currently available for diagnostics, prognostic evaluation, or treatment monitoring of medullary thyroid cancer. In this study of the glycosphingolipids of MTC the most intriguing findings were the presence of $\mathrm{Le}^{\mathrm{y}}$, $\mathrm{Le}^{\mathrm{x}}$, globo $\mathrm{H}$ and the Forssman glycosphingolipids. These aberrations in the glycan structures suggest the potential utility of these compounds as markers for medullary thyroid cancer.

\section{Materials and Methods}

\subsection{Glycosphingolipid Preparations}

This study was performed on MTCs from patients treated at the Department of Surgery, Uppsala University Hospital, Sweden and included biomaterial from Uppsala Biobank, Endocrine tumor collection (Ethical approval 00-128/3.15.2000). Clinical data were extracted through patient chart reviews. The study was approved by the Swedish Ethical Review Authority (No. 2020-06142) and followed the Declaration of Helsinki and the General Data Protection Regulation (GDPR). All patients were given written and verbal information before signing informed consent to participate and agreeing to the use of the information in research.

For the glycosphingolipid analysis, $20 \mathrm{~g}$ of pooled tumor material from 14 different patients was used. The tissues were obtained at surgery. The ABO blood group status of the patients $(\mathrm{A}(n=2), \mathrm{O}(n=2)$ and $\mathrm{B}(n=1))$ was routinely established prior to surgery.

The pooled MTC tissue was kept at $-70^{\circ} \mathrm{C}$. The pooled material was lyophilized, giving dry weight $5.4 \mathrm{~g}$. Isolation of total acid and total non-acid glycosphingolipids was conducted by the method described by Karlsson [13]. The lyophilized material was extracted in two steps in a Soxhlet apparatus with chloroform and methanol (2:1 and 1:9, by volume, respectively). The extract was subjected to mild alkaline hydrolysis and dialysis, followed by separation on a silicic acid column. Acid and non-acid glycosphingolipid fractions were obtained by chromatography on a DEAE-cellulose column. In order to separate the non-acid glycosphingolipids from alkali-stable phospholipids, the non-acid fractions were acetylated and separated on a second silicic acid column, followed by deacetylation and dialysis. Final purifications were carried out by chromatographies on DEAE-cellulose and silicic acid columns.

The amounts of total acid and non-acid glycosphingolipids obtained are provided in Supplementary Table S1.

The total glycosphingolipid fractions were characterized by liquid chromatographyelectrospray mass spectrometry (LC-ESI/MS), thin-layer chromatography, and binding of carbohydrate recognizing ligands (antibodies, lectins, and bacteria) in chromatogram binding assays (see below).

Thereafter, the total non-acid glycosphingolipid fraction was separated by chromatography on an Iatrobeads (Iatron Labs. Inc., Tokyo, Japan; Iatrobeads 6RS-8060) column eluted with increasing amounts of methanol in chloroform. This gave four subfractions, which were denoted fractions $\mathrm{T} 1$ to $\mathrm{T} 4$. 


\subsection{Reference Glycosphingolipids}

Total acid and non-acid glycosphingolipid fractions were isolated as described [13]. Individual glycosphingolipids were isolated by repeated chromatography on silicic acid columns and by HPLC, and identified by mass spectrometry $[15,38]$ and ${ }^{1} \mathrm{H}-\mathrm{NMR}$ spectroscopy [39].

\subsection{Thin-Layer Chromatography}

Thin-layer chromatography was carried out on aluminum- or glass-backed silica gel 60 high performance thin-layer chromatography plates (Merck, Darmstadt, Germany; 105641/105547). Glycosphingolipid mixtures $(40 \mu \mathrm{g})$ or pure glycosphingolipids (2-8 $\mu \mathrm{g})$ were applied to the plates, and eluted with chloroform/methanol/water 60:35:8 (by volume). Chemical detection was carried out with anisaldehyde [40].

\subsection{Chromatogram Binding Assays}

The mouse monoclonal antibodies tested for binding to the glycosphingolipids of human MTC in the chromatogram binding assay are provided in Supplementary Table S2. Binding of the monoclonal antibodies to glycosphingolipids separated on thin-layer chromatograms was carried out as described [41,42]. Chromatograms with separated glycosphingolipids were dipped for $1 \mathrm{~min}$ in diethylether $/ n$-hexane (1:5, by volume) containing $0.5 \%(w / v)$ polyisobutylmethacrylate (Sigma-Aldrich, St. Louis, MO, USA; 100185005B). After drying, the chromatograms were soaked in PBS containing $2 \%$ bovine serum albumin and $0.1 \% \mathrm{NaN}_{3}$ (Solution A), for $2 \mathrm{~h}$ at room temperature. Suspensions of primary monoclonal antibodies diluted 1:100-1:500 (the dilution used for each monoclonal antibody is given in Supplementary Table S2) in Sol. A were gently sprinkled over the chromatograms, followed by incubation for $2 \mathrm{~h}$ at room temperature, followed by washings with PBS. For detection two types of secondary antibodies were used. Firstly, ${ }^{125}$ I-labeled (labeled by the Iodogen method according to the manufacturer's (Pierce/Thermo Fischer Scientific, Stockholm, Sweden; 28600) instructions) rabbit anti-mouse antibodies were diluted to $2 \times 10^{6} \mathrm{cpm} / \mathrm{mL}$ in Solution A, which were incubated for $2 \mathrm{~h}$. Thereafter, the plates were washed six times with PBS, Dried chromatograms were then autoradiographed for 12-24 $\mathrm{h}$ using XAR-5 X-ray films (Carestream/Sigma-Aldrich, St. Louis, MO, USA; 8941114). Other types of secondary antibodies used were alkaline phosphate-conjugated goat anti-mouse antibodies (Sigma-Aldrich, St. Louis, MO, USA; A0162) at a dilution of 1:500, which were incubated for $1 \mathrm{~h}$. Thereafter the reactions were visualized with 5-bromo-4-chloro-3-indolyl phosphate/nitro blue tetrazolium chromogenic substrate (Sigma-Aldrich, St. Louis, MO, USA; B5655-25TAB). Binding of ${ }^{125}$ I-labeled Helix pomatia lectin (Sigma-Aldrich, St. Louis, MO, USA; L3382) to glycosphingolipids on thin-layer chromatograms was carried out as described [43].

\subsection{LC-ESI/MS of Native Acid Glycosphingolipids}

The native acid glycosphingolipid fractions were analyzed by LC-ESI/MS as described [44]. Aliquots of the glycosphingolipid fractions were dissolved in methanol: acetonitrile in proportion 75:25 (by volume) and separated on a $200 \times 0.250 \mathrm{~mm}$ column, packed in-house with $5 \mu \mathrm{m}$ polyamine II particles (YMC Europe GmbH, Dinslaken, Germany). An autosampler, HTC-PAL (CTC Analytics AG, Zwingen, Switzerland) equipped with a cheminert valve $(0.25 \mathrm{~mm}$ bore $)$ and a $2 \mu \mathrm{L}$ loop, was used for sample injection. An Agilent 1100 binary pump (Agilent technologies, Palo Alto, CA, USA) delivered a flow of $250 \mu \mathrm{L} / \mathrm{min}$, which was split in an 1/16" microvolume-T ( $0.15 \mathrm{~mm}$ bore) (Vici AG International, Schenkon, Switzerland) by a $50 \mathrm{~cm} \times 50 \mu \mathrm{m}$ i.d. fused silica capillary before the injector of the autosampler, allowing approximately 2-3 $\mu \mathrm{L} / \mathrm{min}$ through the column. Samples were eluted with an aqueous gradient (A:100\% acetonitrile to B: $10 \mathrm{mM}$ ammonium bicarbonate). The gradient $(0-50 \% \mathrm{~B})$ was eluted for $40 \mathrm{~min}$, followed by a wash step with $100 \% \mathrm{~B}$, and equilibration of the column for $20 \mathrm{~min}$. The samples were analyzed in negative ion mode on a LTQ linear quadropole ion trap mass spectrometer 
(Thermo Electron, San José, CA, USA), with an IonMax standard ESI source equipped with a stainless steel needle kept at $-3.5 \mathrm{kV}$. Compressed air was used as nebulizer gas. The heated capillary was kept at $270{ }^{\circ} \mathrm{C}$, and the capillary voltage was $-50 \mathrm{kV}$. Full scan ( $\mathrm{m} / \mathrm{z}$ 500-1800, two microscan, maximum $100 \mathrm{~ms}$, target value of 30,000) was performed, followed by data-dependent MS $^{2}$ scans (two microscans, maximun $100 \mathrm{~ms}$, target value of 10.000 ) with normalized collision energy of $35 \%$, isolation window of 2.5 units, activation $\mathrm{q}=0.25$ and activation time $30 \mathrm{~ms})$. The threshold for $\mathrm{MS}^{2}$ was set to 500 counts.

Data acquisition and processing were conducted with Xcalibur software (Version 2.0.7). Manual assignment of glycosphingolipid sequences was carried out with the assistance of the Glycoworkbench tool (Version 2.1), and by comparison of retention times and MS 2 spectra of reference glycosphingolipids.

\subsection{Endoglycoceramidase Digestion and LC-ESI/MS}

Endoglycoceramidase II from Rhodococcus spp. (Takara Bio Europe S.A., Gennevilliers, France) was used for hydrolysis of the non-acid glycosphingolipids. The glycosphingolipids $(50 \mu \mathrm{g})$ were resuspended in $100 \mu \mathrm{L} 0.05 \mathrm{M}$ sodium acetate buffer, $\mathrm{pH}$ 5.0, containing $120 \mu \mathrm{g}$ sodium cholate, and sonicated briefly. Thereafter, $1 \mathrm{mU}$ of enzyme was added, and the mixture was incubated at $37^{\circ} \mathrm{C}$ for $48 \mathrm{~h}$. The reaction was stopped by addition of chloroform/methanol/water to the final proportions 8:4:3 (by volume). The oligosaccharide-containing upper phase thus obtained was separated from detergent on a Sep-Pak QMA cartridge (Waters). The eluant containing the oligosaccharides was dried under nitrogen and under vacuum.

Part of the oligosaccharide samples were reduced by adding $20 \mu \mathrm{L}$ of $200 \mathrm{mM} \mathrm{NaBH}_{4}$ in $50 \mathrm{mM} \mathrm{KOH}$ to the samples and incubating at $50^{\circ} \mathrm{C}$ for $2 \mathrm{~h} \mathrm{[15].} \mathrm{The} \mathrm{samples} \mathrm{were} \mathrm{then}$ acidified by adding $10 \mu \mathrm{L}$ of glacial acetic acid, and the oligosaccharides were desalted by cation exchange chromatography, and thereafter evaporated to dryness.

The glycosphingolipid-derived oligosaccharides were resuspended in $50 \mu \mathrm{L}$ water and analyzed by LC-ESI/MS as described [15]. The oligosaccharides were separated on a column $(100 \times 0.250 \mathrm{~mm})$ packed in-house with $5 \mu \mathrm{m}$ porous graphite particles (Hypercarb, Thermo-Hypersil, Runcorn, UK). An autosampler, HTC-PAL (CTC Analytics AG, Zwingen, Switzerland) equipped with a cheminert valve $(0.25 \mathrm{~mm}$ bore $)$ and a $2 \mu \mathrm{L}$ loop, was used for sample injection. An Agilent 1100 binary pump (Agilent technologies, Palo Alto, CA, USA) delivered a flow of $250 \mu \mathrm{L} / \mathrm{min}$, which was split down in an 1/16" microvolume$\mathrm{T}(0.15 \mathrm{~mm}$ bore) (Vici AG International, Schenkon, Switzerland) by a $50 \mathrm{~cm} \times 50 \mu \mathrm{m}$ i.d. fused silica capillary before the injector of the autosampler, allowing approximately 3-5 $\mu \mathrm{L} / \mathrm{min}$ through the column. The oligosaccharides $(3 \mu \mathrm{L})$ were injected on to the column and eluted with an acetonitrile gradient (A: $10 \mathrm{mM}$ ammonium bicarbonate; B: $10 \mathrm{mM}$ ammonium bicarbonate in $80 \%$ acetonitrile). The gradient $(0-45 \%$ B) was eluted for $46 \mathrm{~min}$, followed by a wash step with $100 \% \mathrm{~B}$, and equilibration of the column for $24 \mathrm{~min}$. A $30 \mathrm{~cm} \times 50 \mu \mathrm{m}$ i.d. fused silica capillary was used as transfer line to the ion source.

The oligosaccharides were analyzed in negative ion mode on an LTQ linear quadrupole ion trap mass spectrometer (Thermo Electron, San José, CA, USA). The IonMax standard ESI source on the LTQ mass spectrometer was equipped with a stainless steel needle kept at $-3.5 \mathrm{kV}$. Compressed air was used as nebulizer gas. The heated capillary was kept at $270{ }^{\circ} \mathrm{C}$, and the capillary voltage was $-50 \mathrm{kV}$. Full-scan $(\mathrm{m} / \mathrm{z} 380-2000,2$ microscans, maximum $100 \mathrm{~ms}$, target value of 30,000) were performed, followed by data dependent $\mathrm{MS}^{2}$ scans of the three most abundant ions in each scan ( 2 microscans, maximum $100 \mathrm{~ms}$, target value of 10,000 ). The threshold for $\mathrm{MS}^{2}$ was set to 500 counts. Normalized collision energy was $35 \%$, and an isolation window of $3 \mathrm{u}$, an activation $q=0.25$, and an activation time of $30 \mathrm{~ms}$, was used. Data acquisition and processing were conducted with Xcalibur software (Thermo Scientific, Waltham, MA, USA; Version 2.0.7)).

Manual assignment of glycan sequences was carried out on the basis of knowledge of mammalian biosynthetic pathways, with the assistance of the Glycoworkbench tool (Version 2.1), [45] and by comparison of retention times and $\mathrm{MS}^{2}$ spectra of oligosaccharides 
from reference glycosphingolipids [15]. The raw data files were deposited in Glycopost: https:/ /glycopost.glycosmos.org/entry/GPST000197, accessed on 3 June 2021.

$\alpha-N$-Acetylgalactosaminidase Hydrolysis

The oligosaccharides from total non-acid glycosphingolipid fraction were dissolved in $20 \mu \mathrm{L} 100 \mathrm{mM}$ sodium citrate phosphate buffer (pH 5.0) and digested with $1.5 \mathrm{mU}$ chicken liver $\alpha$ - $N$-acetylgalactosaminidase (Prozyme/Agilent Technologies Sweden AB, Kista, Sweden; GKX5001) at $37^{\circ} \mathrm{C}$ overnight. The sample was cleaned up with Hypersep Hypercarb (Thermo Scientific, Waltham, MA, USA; 60106-301), according to the manufacturer's instructions. Thereafter, the oligosaccharides were analyzed by LC-ESI/MS.

\subsection{Histology and Immunohistochemistry}

For immunohistochemistry, paraffin embedded sections from nine tumor samples (five lymph node metastases and four primary MTC tissues) from five different patients with MTC were utilized (see Supplementary Table S3 for patient characteristics).

Nine MTC samples from the five different patients were included in the pooled material for glycosphingolipid preparation, and three non-neoplastic follicular thyroid tissue samples, were fixed in buffered $4 \%$ paraformaldehyde, dehydrated, and embedded in paraffin. Subsequently, $4 \mu \mathrm{m}$ sections were mounted on Superfrost Plus glass slides (VWR, Radnor, PA, USA; 630-0951) and microwave treated for antigen retrieval. Immunostaining was performed after pretreatment with Diva Decloaker 20X (Biocare Medical, Pacheco, CA, USA; DV2005 L2J) at $95^{\circ} \mathrm{C}$ for $40 \mathrm{~min}$. The primary antibodies used (see Supplementary Table S2) were anti-Forssman, anti-blood group A, anti-Globo $\mathrm{H}$, anti-Le ${ }^{\mathrm{x}}$, and anti-Le ${ }^{\mathrm{y}}$, all diluted 1:50. Rat HRP-polymer kit (Biocare Medical RT517) or MACH4 Universal HRPpolymer detection system (Biocare Medical; M4U534, together with betazoid DAB substrate kit (Biocare Medical; BDB2004) was used for detection of bound antibodies. Nuclei were counterstained with Tacha's automated hematoxylin (Biocare Medical; NM-HEM).

Supplementary Materials: The following are available online at https:/ / www.mdpi.com/article/10.3 390/ijms221910463/s1.

Author Contributions: All authors have full access to the data in the study and take responsibility for the integrity of the data and accuracy of the data analysis. Conceptualization, K.S., A.T., O.N. and S.T.; Methodology, C.J., S.T. and K.S.; Validation, C.J., S.T., K.S. and O.N.; Formal Analysis, C.J., S.T., and K.S.; Investigation, C.J., S.T., and K.S.; Resources, S.T.; Data Curation, S.T.; Writing-Original Draft Preparation, S.T. and K.S.; Writing-Review and Editing, K.S., A.T., C.J., O.N. and S.T.; Project Administration, S.T.; Funding Acquisition, S.T., K.S. and O.N. All authors have read and agreed to the published version of the manuscript.

Funding: This study was funded by grants from the Swedish Cancer Foundation (S.T.), Lisa and Johan Grönbergs Foundation (K.S.), Anna-Lisa och Bror Björnsson Stiftelse (A.T.), the Gustafsson Foundation (O.N.) and Eriksson Foundation (O.N.).

Institutional Review Board Statement: This study was performed on medullary thyroid cancers from patients treated at the Department of Surgery, Uppsala University Hospital, Sweden and included biomaterial from Uppsala Biobank, Endocrine tumor collection (Ethical approval 00128/3.15.2000). Clinical data was extracted through patient chart review. The study ßwas approved by the Swedish Ethical Review Authority (No. 2020-06142), and followed the Declaration of Helsinki and the General Data Protection Regulation (GDPR).

Informed Consent Statement: All patients involved in the study were given written and verbal information before signing informed consent to participate and agreeing to the use of the information in research.

Data Availability Statement: The raw data files from LC-ESI/MS were deposited in Glycopost: https:/ / glycopost.glycosmos.org/entry/GPST000197, accessed on 3 June 2021.

Acknowledgments: We gratefully acknowledge Peter Stålberg, Department of Surgical Sciences, Uppsala University, for his expert assistance with histologic and immunohistochemical analyses. 
Conflicts of Interest: The authors declare no conflict of interest.

\begin{abstract}
Abbreviations
MEN2B: multiple endocrine neoplasia type 2B; MTC, medullary thyroid carcinoma; LC-ESI/MS, liquid chromatography electrospray ionization mass spectrometry.
\end{abstract}

\title{
References
}

1. Alexander, E.K.; Pearce, E.N.; Brent, G.A.; Brown, P.S.; Chen, H.; Dosiou, C.; Grobman, W.A.; Laurberg, P.; Lazarus, J.H.; Mandel, S.J.; et al. Guidelines of the American Thyroid Association for the diagnosis and management of thyroid disease during pregnancy and the postpartum. Thyroid 2017, 27, 315-389. [CrossRef]

2. Williams, E.D. Histogenesis of medullary carcinoma of the thyroid. J. Clin. Pathol. 1966, 19, 114-118. [CrossRef]

3. Kurzrock, R.; Sherman, S.I.; Ball, D.W.; Forastiere, A.A.; Cohen, R.B.; Mehra, R.; Pfister, D.G.; Cohen, E.E.W.; Janisch, L.; Nauling, F.; et al. Activity of XL184 (Cabozantinib), an oral tyrosine kinase inhibitor, in patients with medullary thyroid cancer. J. Clin. Oncol. 2011, 29, 2660-2666. [CrossRef]

4. Wells, S.A., Jr.; Robinson, B.G.; Gagel, R.F.; Dralle, H.; Fagin, J.A.; Santoro, M.; Baudin, E.; Elisei, R.; Jarzab, B.; Vasselli, J.R.; et al. Vandetanib in patients with locally advanced or metastatic medullary thyroid cancer: A randomized, double-blind phase III trial. J. Clin. Oncol. 2012, 30, 134-141. [CrossRef] [PubMed]

5. Hakomori, S. The general concept of tumor-associated carbohydrate antigens: Their chemical, physical and enzymatic basis. In Gangliosides and Cancer; Oettgen, H.F., Ed.; VCH Verlagsgesellschaft mbH: Weinheim, Germany, 1989; pp. 57-68.

6. Fuster, M.M.; Esko, J.D. The sweet and sour of cancer: Glycans as novel therapeutic targets. Nat. Rev. Cancer 2005, 5, 526-542. [CrossRef] [PubMed]

7. Varki, A.; Kannagi, R.; Toole, B.P. Glycosylation changes in cancer. In Essentials of Glycobiology; Varki, A., Cummings, R.D., Esko, J.D., Freeze, H.H., Stanley, P., Bertozzi, C.R., Hart, G.W., Etzler, M.E., Eds.; Cold Spring Harbor Laboratory Press: Cold Spring Harbor, NY, USA, 2009; pp. 617-632.

8. Pearce, O.M.T. Cancer glycan epitopes: Biosynthesis, structure and function. Glycobiology 2018, 28, 670-696. [CrossRef] [PubMed]

9. Miyoshi, E.; Ito, Y.; Miyoshi, Y. Involvement of aberrant glycosylation in thyroid cancer. J. Oncol. 2010, 2010, 816595. [CrossRef] [PubMed]

10. Zabczyńska, M.; Kozłowska, K.; Pocheć, E. Glycosylation in the thyroid gland: Vital aspects of glycoprotein function in thyrocyte physiology and thyroid disorders. Int. J. Mol. Sci. 2018, 19, 2792. [CrossRef] [PubMed]

11. Bouchon, B.; Portoukalian, J.; Bornet, H. Major gangliosides in normal and pathological human thyroids. Biochem. Int. 1985, 10, 531-538. [PubMed]

12. Mariano, A.; Di Carlo, A.; Macchia, P.E.; Pisano, G.; Parmeggiani, U.; Macchia, V. Gangliosides and phospholipids in human thyroids responsive and unresponsive to thyrotropin. J. Endocrinol. Invest. 1990, 13, 817-823. [CrossRef] [PubMed]

13. Karlsson, K.A. Preparation of total non-acid glycolipids for overlay analysis of receptors for bacteria and viruses and for other studies. Meth. Enzymol. 1987, 138, 212-220. [CrossRef]

14. Säljö, K.; Thornell, A.; Jin, C.; Stålberg, P.; Norlén, O.; Teneberg, S. Characterization of glycosphingolipids in the human parathyroid and thyroid glands. Int. J. Mol. Sci. 2021, 22, 7044. [CrossRef]

15. Karlsson, H.; Halim, A.; Teneberg, S. Differentiation of glycosphingolipid-derived glycan structural isomers by liquid chromatography-mass spectrometry. Glycobiology 2010, 20, 1103-1116. [CrossRef]

16. Chai, W.; Piskarev, V.; Lawson, A.M. Negative-ion electrospray mass spectrometry of neutral underivatized oligosaccharides. Anal. Chem. 2001, 73, 651-657. [CrossRef]

17. Svensson, L.; Hult, A.K.; Stamps, R.; Ångström, J.; Teneberg, S.; Storry, J.R.; Jørgensen, R.; Rydberg, L.; Henry, S.M.; Olsson, M.L. Forssman expression on human erythrocytes: Biochemical and genetic evidence of a new histo-blood group system. Blood 2013, 121, 1459-1468. [CrossRef]

18. Westman, J.S.; Benktander, J.; Storry, J.R.; Peyrard, T.; Hult, A.K.; Hellberg, Å.; Teneberg, S.; Olsson, M.L. Identification of the molecular and genetic basis of PX2, a glycosphingolipid blood group antigen lacking on globoside-deficient erythrocytes. J. Biol. Chem. 2015, 290, 18505-18518. [CrossRef] [PubMed]

19. Jin, C.; Barone, A.; Borén, T.; Teneberg, S. Helicobacter pylori binding non-acid glycosphingolipids in the human stomach. J. Biol. Chem. 2018, 293, 17248-17266. [CrossRef] [PubMed]

20. Sanchez, J.F.; Lescar, J.; Chazalet, V.; Audfray, A.; Gagnon, J.; Alvarez, R.; Breton, C.; Imberty, A.; Mitchell, E.P. Biochemical and structural analysis of Helix pomatia agglutinin. A hexameric lectin with a novel fold. J. Biol. Chem. 2006, 281, 20171-20180. [CrossRef] [PubMed]

21. Babál, P.; Janega, P.; Cerná, A.; Kholová, I.; Brabencová, E. Neoplastic transformation of the thyroid gland is accompanied by changes in cellular sialylation. Acta Histochem. 2006, 108, 133-140. [CrossRef] [PubMed]

22. Vierbuchen, M.; Schröder, S.; Larena, A.; Uhlenbruck, G.; Fischer, R. Native and sialic acid masked Lewis(a) antigen reactivity in medullary thyroid carcinoma. Distinct tumour-associated and prognostic relevant antigens. Virchows Arch. 1994, 424, $205-211$. [CrossRef] [PubMed] 
23. Krzeslak, A.; Gaj, Z.; Pomorski, L.; Lipinska, A. Sialylation of intracellular proteins of thyroid lesions. Oncol. Rep. 2007, 17, 1237-1242. [CrossRef]

24. Ito, M.; Yamagata, T. Purification and characterization of glycosphingolipid-specific endoglycosidases (endoglycoceramidases) from a mutant strain of Rhodococcus sp. Evidence for three molecular species of endoglycoceramidase with different specificities. J. Biol. Chem. 1989, 264, 9510-9519. [CrossRef]

25. Li, Y.T.; Chou, C.W.; Li, S.C.; Kobayashi, U.; Ishibashi, Y.h.; Ito, M. Preparation of homogenous oligosaccharide chains from glycosphingolipids. Glycoconj. J. 2009, 26, 929-933. [CrossRef]

26. Yu, J.; Hung, J.T.; Wang, S.H.; Cheng, J.Y.; Yu, A.L. Targeting glycosphingolipids for cancer immunotherapy. FEBS Lett. 2020, 594, 3602-3618. [CrossRef]

27. Cheng, S.P.; Yang, P.S.; Chien, M.N.; Chen, M.J.; Lee, J.J.; Liu, C.L. Aberrant expression of tumor-associated carbohydrate antigen Globo H in thyroid carcinoma. J. Surg. Oncol. 2016, 114, 853-858. [CrossRef]

28. Hult, A.K.; McSherry, E.; Moller, M.; Olsson, M.L. GBGT1 is allelically diverse but dispensable in humans and naturally occurring anti-FORS1 shows an ABO-restricted pattern. Transfusion 2018, 58, 2036-2045. [CrossRef]

29. Luetscher, R.N.D.; McKitrick, T.R.; Gao, C.; Mehta, A.Y.; Mcquillan, A.M.; Kardish, R.; Boligan, K.F.; Song, X.; Lu, L.; HeimburgMolinaro, J.; et al. Unique repertoire of anti-carbohydrate antibodies in individual human serum. Sci. Rep. 2020, 10, 15436. [CrossRef]

30. Hakomori, S.; Wang, S.M.; Young, W.W., Jr. Isoantigenic expression of Forssman glycolipid in human gastric and colonic mucosa: Its possible identity with A-like "antigen" in human cancer. Proc. Natl. Acad. Sci. USA 1977, 74, 3023-3027. [CrossRef] [PubMed]

31. Breimer, M.E. Chemical and immunological identification of the forssman pentaglycosylceramide in human kidney. Glycoconj. J. 1985, 2, 375-385.

32. Hult, A.K.; Olsson, M.L. The FORS awakens: Review of a blood group system reborn. Immunohematology 2017, 33 , 64-72. [CrossRef] [PubMed]

33. Campbell, C.T.; Gulley, J.L.; Oyelaran, O.; Hodge, J.W.; Schlom, J.; Gildersleeve, J.C. Humoral response to a viral glycan correlates with survival on PROSTVAC-VF. Proc. Natl. Acad. Sci. USA 2014, 111, E1749-E1758. [CrossRef]

34. Vierbuchen, M.; Larena, A.; Schröder, S.; Hanisch, F.G.; Ortmann, M.; Larena, A.; Uhlenbruck, G.; Fischer, R. Blood group antigen expression in medullary carcinoma of the thyroid. An immunohistochemical study on the occurrence of type 1 chain-derived antigens. Virchows Arch. B Cell. Pathol. Incl. Mol. Pathol. 1992, 62, 79-88. [CrossRef]

35. Larena, A.; Vierbuchen, M.; Fischer, R. Blood group antigen expression in malignant tumors of the thyroid: A parallel between medullary and nonmedullary carcinomas. Langenbecks Arch. Chir. 1995, 380, 269-272. [CrossRef]

36. González-Cámpora, R.; García-Sanatana, J.A.; i Heras, M.M.J.; Salaverri, C.O.; Vázquez-Ramírez, F.J.; Argueta-Manzano, O.E.; Galera-Davidson, H. Blood group antigens in differentiated thyroid neoplasms. Arch. Pathol. Lab. Med. 1998, 122, 957-965. [PubMed]

37. Manimala, J.C.; Roach, T.A.; Li, Z.; Gildersleeve, J.C. High-throughput carbohydrate microarray profiling of 27 antibodies demonstrates widespread specificity problems. Glycobiology 2007, 17, 17C-23C. [CrossRef]

38. Samuelsson, B.E.; Pimlott, W.; Karlsson, K.A. Mass spectrometry of mixtures of intact glycosphingolipids. Meth. Enzymol. 1990, 193, 623-646. [CrossRef]

39. Koerner, T.A.W., Jr.; Prestegard, J.H.; Demou, P.C.; Yu, R.K. High-resolution proton NMR studies of gangliosides. 1. Use of homonuclear spin-echo J-correlated spectroscopy for determination of residue composition and anomeric configurations. Biochemistry 1983, 22, 2676-2687. [CrossRef]

40. Waldi, D. Sprühreagentien für die dünnschicht-chromatographie. In Dünnschicht-Chromatographie; Stahl, E., Ed.; Springer: Berlin, Germany, 1962; pp. 496-515.

41. Barone, A.; Benktander, J.; Ångström, J.; Aspegren, A.; Björquist, P.; Teneberg, S.; Breimer, M.E. Structural complexity of non-acid glycosphingolipids in human embryonic stem cells grown under feeder-free conditions. J. Biol. Chem. 2013, 288, 10035-10050. [CrossRef] [PubMed]

42. Barone, A.; Säljö, K.; Benktander, J.; Blomqvist, M.; Månsson, J.E.; Johansson, B.R.; Mölne, J.; Aspegren, A.; Björquist, P.; Breimer, M.E.; et al. Sialyl-lactotetra: A novel cell surface marker of undifferentiated human pluripotent stem cells. J. Biol. Chem. 2014, 289, 18846-18859. [CrossRef] [PubMed]

43. Teneberg, S.; Jovall, P.Å.; Ångström, J.; Karlsson, K.A. Characterization of binding of Galß4GlcNAc-specific lectins from Erythrina christagalli and Erythrina corallodendron to glycosphingolipids. Detection, isolation and characteriztion of a novel glycosphingolipid of bovine buttermilk. J. Biol. Chem. 1994, 269, 8554-8563. [CrossRef] [PubMed]

44. Johansson, M.M.; Dedic, B.; Lundholm, K.; Branzell, F.B.; Barone, A.; Benktander, J.; Teneberg, S. Characterization of moose intestinal glycosphingolipids. Glycoconj. J. 2015, 32, 393-412. [CrossRef] [PubMed]

45. Ceroni, A.; Maass, K.; Geyer, H.; Geyer, R.; Dell, A.; Haslam, S.M. GlycoWorkbench: A Tool for the Computer-Assisted Annotation of Mass Spectra of Glycans. J. Proteome Res. 2008, 7, 1650-1659. [CrossRef] 